Historic, archived document

Do not assume content reflects current scientific knowledge, policies, or practices. 
The Forest Service of the U.S. Department of Agriculture is dedicated to the principle of multiple use management of the Nation's forest resources for sustained yields of wood, water, forage, wildlife, and recreation. Through forestry research, cooperation with the States and private forest owners, and management of the National Forests and National Grasslands, it strives - as directed by Congress - to provide increasingly greater service to a growing Nation.

The U.S. Department of Agriculture is an Equal Opportunity Employer. Applicants for all Department programs will be given equal consideration without regard to age, race, color, sex, religion, or national origin.

Pacific Northwest Research Station 319 S.W. Pine St.

P.O. Box 3890

Portland, Oregon 97208 
United States Department of Agriculture

Forest Service

Pacific Northwest Research Station

Research Paper PNW-350

January 1986

U.SS

PSW FOREST AND RANGE EXPERIAIENT STATION

$$
\text { MAR: } 01986
$$

\section{Economic Impacts}

of Interregional Competition in the Forest Products Industry During the 1970's

\section{The South and the Pacific Northwest}

\author{
Con H Schallau and Wilbur R. Maki
}

STATION LIBPARY COPY

PNWSOUTHCOMPETIT IONPNWSOUTHCOMPETI TIONPNWSOUTHCOMPETITIONPNWSOUTHCOMPET ITIONPNW SOUTHCOMPETITIONPNWSOUTHCOMPET IT IONPNWSOUTHCOMPETIT IONP NWSUUTHCOMPET IT I ONPNWSOU THCOMPET 'WSOUTHCOMPETITIONPNWSOUTHCOMPETITIONPNWSOUTHCOMPETITIONPNWSOUTHC OMPETIT WA THCOMPETITIONPNWSOUTHCOMPETITIONPNWSOUTHCUIMPET IT IONPNWSOUTHCOMP ETITIO) IPETITIONPNWSOUTHCOMPETITIONPNWSOUTHCOMDETITIONPNWSOUTHCOMPETI TIONPN OTIONPNWSOUTHCOMPETITIUNPNWSOUTHCUMPE TUNPNWSOUTHCUMPETITIO NPNWSOL WSOUTHCG 119 WPETIT

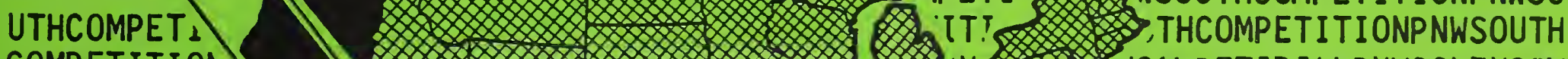
COMPETITION: PETITIONPNh ITIONPNWSOL ONPNWSOUTHCC NWSOUTHCOMPE OUTHCOMPETITI HCOMPETITIONPNW MPETITIONPNWSOUTHCU. TITIONPNWSOUTHCOMPETIIIONPA IONPNWSOUTHCOMPETITIONPNWSOL PNWSOUTHCOMPETITIONPNWSOUTHC, SOUTHCOMPETITIONPNWSOUTHCOMPE THCOMPETITIONPNWSOUTHCOMPETITI OMPETITIONPNWSOUTHCOMPETITIONPA ETITIONPNWSOUTHCOMPETITIONPNWSO. TIONPNWSOUTHCOMPETITIONPNWSOUTHCL NPNWSOUTHCOMPETITIONPNWSOUTHCOMPE

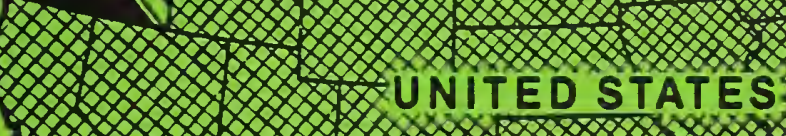
IMPETITIONPNWSOUTHCOMPET Th WSOUTHCOMPETITIONPNWSOUTHCOMPETITIONPNW: UTHCOMPETITIONPNWSOUTHCOMPETITIONPNWSOUT, IETITIONPNWSOUTHCOMPEI. NPNWSUUTH COMPETITIONPNWSOUTHCOMPETITIONPNWSOUTHCOMPL. TIONPNWSOUTHCOMPETITION NWSOUTHCOM PETIT I ONP NWSOUTHCOMPETIT IONPNWSOUTHCOMPET I I I NNPNWSOUTHCCMPET IT IONPNWSOLTHCOMPET ITIONPNWSOUTHCOMPET ITIONPNWSOUTHCOMPETITIONPNWSOUTHCOMPETITI ONPNWSOUTHCOMPETITI ONPNWSOUTHCOMPET ITI ONPNWSOUTHCOMPET IT I ONPNWSOUTHCOMPETI I IONPNW SOUTHC UMPET IT I UNP NWSOUTHCOMPETI I I ONPNWSOUTHCOMPETIT IONPNWSOUTHCOMPETITIONPNWSOUTHCOMPETITIONPNWS OUTHCOMPETI TIONPNWSOUTHCOMPETI I I ONPNWSOUTHCOMPET ITI UNPNWSUUTHCOMPET IT IONPNWSOUT HCOMPETITIONPNWSOUTHCOMPETI I IONPNWSOUTHCOMPE TI I IONPNWSOUTHCOMPETI TIONPNWSOUTHCO MPET I I IONPNWSOUTHCOMPETITI ONPNWSOUTHCCMPET IT I GNPNWSOUTHCOMPET IT I ONPNWSOUTHCOMPE TITIONPNWSOUTHCOMPETITIONPNWSOUTHCOMPETITIONPNWSOUTHCOMPETITIONPNWSOUTHCOMPETIT 
States
AL Alabama
AR Arkansas
FL Florida
GA Georgia
KY Kentucky
LA Louisiana
MS Mississippi
NC North Carolina
OK Oklahoma
OR Oregon
SC South Carolina
TN Tennessee
TX Texas
VA Virginia
WA Washington

\section{Regions}

ESC East South Central

MSO Mid-South

PNW Pacific Northwest (Oregon and Washington)

RON Rest of Nation

SAT South Atlantic

SO South

US United States

WSC West South Central
Industries

FPI Forest Products Industry

LWP Lumber and Wood Products

PAP Paper and Allied Products

WF Wood Furniture 


\section{Abstract}

\section{Highlights}

Schallau, Con H; Maki, Wilbur R. Economic impacts of interregional competition in the forest products industry during the 1970's: the South and the Pacific Northwest. Res. Pap. PNW-350. Portland, OR: U.S. Department of Agriculture, Forest Service, Pacific Northwest Research Station; 1986. 44 p.

Until the 1970's, the Pacific Northwest dominated national markets for softwood lumber and plywood. During the 1970's, however, the region's share declined while production increased in the South. Meanwhile, the South's and the Pacific Northwest's shares of the Nation's employment in lumber and wood products declined. This resulted mainly from the increase in lumber imports from Canada and the construction of new, state-of-the-art plywood mills in the South. Trends in Canada and the South suggest that the Pacific Northwest could regain its dominant position as the supplier of solid softwood products. Although employment in the forest products industry will unlikely return to past levels, the industry will continue to play an important role in the region's economic growth and development.

Keywords: Economic impact, interregional competition, economics (forest products industries), shift-share analysis, Canada, Pacific Northwest, South.

- The Pacific Northwest's share of the Nation's employment in the forest products industry declined substantially between 1970 and 1980. Nevertheless, this industry continued to be a major source of export dollars. In 1980, the forest products industry was still the largest basic industry in Oregon and the second largest in Washington. In most of the region's nonmetropolitan areas, the forest products industry continued to be the mainstay of local economies.

- In 1980, average annual wage and salary earnings in the South's forest products industry were 30 percent less than those in the Pacific Northwest. Furthermore, between 1970 and 1980 earnings increased more in the Pacific Northwest than in the South.

- Despite higher costs for wages and transportation, profits before taxes per worker hour in 1977 were considerably higher for the forest products industry in the Pacific Northwest (\$11.57) than in the South (\$8.97). After the collapse of the housing market in the late 1970's, profits plummeted. The decline was substantially greater in the Pacific Northwest than in the South. In 1982, profits per worker hour in the South $(\$ 8.80)$ were higher than in the Pacific Northwest (\$7.43).

- Overall, the South increased its share of the Nation's employment in the forest products industry between 1970 and 1980. The mid-South, however, resembled the Pacific Northwest in trends in employment, earnings, value added, and profits.

- During the 1970's, the loss of forest products employment in the Pacific Northwest was the result of increased lumber imports from Canada, as well as competition from southern mills. 
- Without softwood lumber imports from Canada, domestic lumber prices would have increased more than they did during the 1970's and, therefore, would have prompted more use of wood substitutes. So, although Canadian lumber imports cost domestic jobs in the short run, they could result in higher future employment in the region's forest products industry.

- The current relative importance of North American softwood-producing areas will not persist. Recent forecasts of a shortfall in the production of lumber in Canada and the unanticipated leveling off of softwood timber inventories in the South suggest that the Pacific Northwest can again become the Nation's dominant supplier of softwood lumber and plywood. A shortfall in Canadian production, however, may not increase employment in the region's forest products industry. Unless the region's industry can reduce costs, higher product prices and more use of substitutes may ensue. Consequently, measures designed to reduce the cost of raw material, labor, and processing will enhance the forest products industry's contribution to future growth and development of the region. 
1 Introduction

2 Overview of the Region's Economy

2 The Region's Work Force

3 Components of the Region's Economic Base

4 Oregon's Economic Base Industries

5 Washington's Economic Base Industries

6 Geographical Importance of the Region's Forest Products Industry

8 Composition of the Region's Forest Products Industry

9 Average Annual Wage and Salary Earnings per Worker

10 Value Added by the Forest Products Industry

11 Profits Before Taxes

12 Comparing the Forest Products Industries of the Pacific Northwest and the South

12 Importance of the Industry

13 A Comparison of Industry Composition

15 Growth of Employment

16 Average Annual Wage and Salary Earnings per Worker

17 Shift in Shares of Employment and Earnings

19 The Diversity of the South's Timber-Based Economy

20 The Resemblance of the Pacific Northwest to the Mid-South

21 Shift in Shares of Employment and Earnings, by Industry Segment

23 Changes in Value Added by the Forest Products Industry

24 Profits Decrease After the Collapse of the Housing Market

25 Competition in the South

26 The Importance of the Canadian Connection

28 Anticipating Future Employment

30 Literature Cited

32 Appendix 1

32 Tables

44 Appendix 2

44 Oregon Counties by Sub-State Planning and Development Districts 44 Washington Counties by Sub-State Planning and Development Districts 

In colonial times, timber was harvested in the Northeastern States for export as well as for local needs. As timber supplies were depleted, harvesting proceeded westward to the Lake States. By the turn of the century the virgin pine stands in the Lake States were gone, so the forest products industry moved to the South and West. The South's old-growth pine was depleted by the mid-1920's, leaving the Pacific Northwest with the dominant role of producing timber products for national and international markets.

Little timber was harvested from public land in the Pacific Northwest until after 1950; private supplies were adequate to meet the forest products industry's needs. But by the end of the 1960's many private owners had liquidated their old growth, and the industry and dependent communities began to rely increasingly on timber from public land.

Throughout the 1960's, the Pacific Northwest continued to dominate the Nation's softwood lumber and plywood markets, but during the 1970's the situation began to change-in favor of the South. The shift to the South was driven by the maturing of second-growth pine stands. The southern pine plywood industry, which did not exist in 1960, highlighted the phenomenal increase in the capacity for manufacturing softwood. By 1980 it accounted for approximately one-half the Nation's softwood plywood production (Dickerhoof and others 1982).

The region's lumber industry also experienced competition from southern producers. In 1960, for example, lumber mills in the Douglas-fir region shipped nearly 60 percent of their output to destinations east of the Mississippi River. By 1980 , eastern markets accounted for only 20 percent. 1 / In addition, the South's paper and allied products manufacturing capacity also was expanded and modernized. These shifts were accelerating as the supply of privately owned old growth was diminishing and the prices for public timber were being bid up in the Pacific Northwest.

Since the recession of 1981 and 1982, for the first time since World War II, recovery of the region's forest products industry from a nationwide recession has advanced more rapidly in the South. Why? Because the industry in Oregon and Washington was undergoing a fundamental change that had little to do with shortterm fluctuations in the Nation's economy. This change was due to comparatively higher prices for timber in the Pacific Northwest and to more competition for lumber and plywood markets east of the Mississippi River.2/

\footnotetext{
1/ Unpublished keynote address of the Western Forest Economists (WFE) meeting, May 1980, by C.W.

Bingham, Weyerhaeuser Company, Tacoma, WA 98477.

21 Railroad rates did not contribute to the South's growing advantage (Cardellichio 1980). In fact, between 1970 and 1980 , real railroad rates for the South increased while they decreased for the Pacific Northwest.
} 
Heavy dependency on the forest products industry has stymied the economies of Oregon and Washington. State and local leaders throughout the region are searching for ways to spark economic growth and development. Although various proposals for stimulating the forest products industry have surfaced (for example, increasing exports to foreign markets), emphasis has focused on diversifying the region's economy.

Diversification will be a slow process. Opportunities for attracting new industries are limited for the timber-dependent communities in nonmetropolitan areas. These communities will rely indefinitely on the forest products industry as the major source of jobs and income. In turn, the region's forest products industry will rely heavily on public forest lands for raw material until the beginning of the next century when the supply from private lands is expected to increase. Therefore, in the immediate future, public forest management policies will have a direct bearing on the economic vitality of the region's timber-dependent communities.

The future of the region's forest products industry cannot be adequately assessed without looking back to see where it and that of the South have been. The purpose of this study is to examine the changing role and performance of the forest products industry in the two regions during the 1970's. We hope the historical and interregional perspective in this report will help State and local leaders identify where forest management policies can be modified so that the region's timber-dependent communities can better adjust to changing economic conditions.

This report is divided into two major sections. The first describes changes in the Pacific Northwest's forest products economy between 1970 and 1980 . The second section compares these changes with changes in the South.

Estimates of employment and earnings shown in this report were derived from unpublished U.S. Department of Commerce data. All reference in dollar amounts are in constant 1977 dollars.

This report is a companion to a series of reports for each of the 13 Southern States.

Overview of the Region's Economy The Region's Work Force
The Pacific Northwest's estimated full- and part-time work force in 1980 included an estimated 3.0 million employees and proprietors (see appendix 1, table 1, for sources of data on employment and earnings). The work force grew more rapidly between 1970 and 1980 than did the Nation's average (31.8 percent versus 22.3 percent). Furthermore, total earnings-wage and salary payments and proprietorial income-also grew faster than the national average. The region's earnings increased by 52.1 percent compared with 27.4 percent for the Nation. 
As can be seen in the following tabulation, manufacturing, services, and retail trade were the region's three largest employer categories. Agriculture and manufacturing were more important in Oregon than in Washington, but services and Federal employment were more important in Washington:

\section{Employers}

Percent of total employment, 1980

Major industry groups:

Oregon Washington United States

Agriculture (includes

self-employed

and wage and salary

workers)

Mining

6.16

5.35

4.39

Construction

.16

.16

Manufacturing (including the

3.73

4.76

4.08

forest products industry)

Transportation,

17.22

15.77

19.15

communication, and

public utilities

4.83

4.70

4.84

Wholesale trade

5.41

5.14

4.97

Retail trade

Finance, insurance, and real

15.07

14.42

14.18

estate

4.82

4.85

4.95

Services

16.24

17.24

18.22

Federal civilian

2.36

3.44

2.81

Federal military

1.10

3.49

2.30

13.93

Nonfarm proprietors

All industries

$100.00 \quad 100.00$

100.00

Components of the Region's Economic Base
Along with total employment there is another and perhaps more important way to judge an industry's contribution to a region's economy. For forest resourcedependent communities to grow and develop, they must attract new dollars from the outside world. The industries that bring in new dollars by exporting products and services beyond local boundaries (that is, to buyers elsewhere in the region and in other States and nations) constitute an area's economic base. The growth of large geographical areas is less dependent on exports than is the growth of smaller, more localized areas. The United States, for example, is less dependent on exports than is Eugene, Oregon.

Generally speaking, most manufacturing employment is classified as economic base (or "basic"), whereas service or "residentiary" employment (for example, barber shops, realty firms, schools, and local government) is primarily geared to producing for local needs. Some portion of the latter is also basic. For example, Federal military spending provides national defense for all the Nation's citizens. Furthermore, taxpayers outside the Pacific Northwest help support this activity. Consequently, Federal military employment qualifies as a basic industry.

Residentiary employment is supported by the economic base. Money flowing in provides income for wage earners and entrepreneurs to spend on locally purchas- 
Oregon's Economic Base Industries

ed goods and services. In most cases, the economic growth of a region depends on the success of its economic base.

We used excess employment and excess earnings to identify the industries comprising the economic base of the Pacific Northwest (Bendavid 1974). Because of differences in average wages between industries, a particular industry might account for a substantially different proportion of basic employment than of basic earnings.

Determination of the economic base proceeded from the assumption that the national distribution of employment and earnings among industries is the norm. Any industry with employment or earnings in excess of this norm is considered to be producing for export markets outside the region (or sub-State district) and is part of the Pacific Northwest's economic base. The percentage of excess employment or earnings serves as an indicator of the region's dependency on a particular industry for generating new dollars from outside the region. (Tables 2 and 3 , appendix 1 , show how the industry-dependency indicators for Oregon and Washington were calculated.) A particular industry may be basic at the local level but not at the State level, as is indicated in the discussion of timber-related industries in Oregon and Washington and their sub-State regions.

In 1980, 10 industries accounted for most of Oregon's economic base:

\section{Economic base for Oregon}

Forest products industry $3 /$

Self-employed (nonagricultural)

Agriculture (includes self-employed and wage and salary workers)

Retail trade

Instruments and related equipment

Wholesale trade

Food and kindred products

Trucking and warehousing Hotel and other lodging

Mobile homes

\section{Total}

All other basic industries

All basic industries

\begin{tabular}{|c|c|c|c|}
\hline \multicolumn{2}{|c|}{ Employment } & \multicolumn{2}{|c|}{ Earnings } \\
\hline 1970 & 1980 & 1970 & 1980 \\
\hline \multicolumn{4}{|c|}{ (Percent of economic base) } \\
\hline 47.6 & 38.3 & 52.1 & 44.7 \\
\hline 15.0 & 18.9 & 14.5 & 17.1 \\
\hline 11.6 & 14.0 & 5.8 & 3.8 \\
\hline 4.6 & 8.1 & 7.4 & 7.9 \\
\hline 0 & 6.7 & 0 & 6.2 \\
\hline 3.7 & 3.8 & 4.7 & 3.1 \\
\hline 4.7 & 2.8 & 3.1 & 1.3 \\
\hline 1.7 & 1.7 & 3.0 & 3.3 \\
\hline 1.9 & 1.4 & .5 & 0 \\
\hline .9 & 1.1 & .9 & 1.3 \\
\hline 91.7 & 96.8 & 92.0 & 88.7 \\
\hline 8.3 & 3.2 & 8.0 & 11.3 \\
\hline 100.0 & 100.0 & 100.0 & 100.0 \\
\hline
\end{tabular}

${ }^{3 /}$ For the purposes of this analysis, the forest products industry is comprised of (1) lumber and wood products (SIC 24) except mobile homes manufacturing (SIC 2451); (2) wood furniture manufacturing (SIC 2511, 2512, 2517. 2521,2541 ), and paper and allied products manufacturing (SIC 26). Further disaggregation into primary and secondary processing was not feasible because of nondisclosure of data. 
Washington's Economic Base Industries

The contribution of these industries to Oregon's export base did not change much between 1970 and 1980. The ranking of individual industries, however, is noteworthy. Agriculture, for example, was more important in 1980 than in 1970 in terms of basic employment, but less important in terms of basic earnings. The disproportionate increase in employment was due in part to the increasing number of parttime farmers.

Tourism is not a standard industrial classification. "Retail trade" and "Hotel and other lodging" industries, however, include most tourism activity. Between 1970 and 1980 , tourism's share of basic employment increased whereas its share of basic earnings remained constant.

The forest products industry's contribution declined between 1970 and 1980. Nevertheless, it was still the State's most important industry. Furthermore, the contribution of the forest products industry to Oregon's economic base in 1970 and 1980 was underestimated because many of the individuals engaged in logging and hauling were classified as self-employed. Also, some Federal civilian employment and earnings are part of forest management activities.

A major component of Oregon's high technology industry (that is, instruments and related equipment) did not qualify as a basic industry in 1970. By 1980, however, it accounted for a modest portion of the State's economic base. Unlike the forest products industry, however, this industry accounted for a smaller portion of basic earnings than it did of basic employment.

During the 1970's, the importance of Washington's aerospace industry (included in transportation equipment, excluding motor vehicles) grew in terms of both employment and earnings, whereas the forest products industry declined:

\section{Economic base for Washington}

Transportation equipment, excluding motor vehicles

Forest products industry

Agriculture (includes self-employed and wage and salary workers)

Federal military

Self-employed (nonagricultural)

Construction

Federal civilian

Retail trade

Nonprofit organizations

Water transportation

Wholesale trade

$$
\text { Total }
$$

All other basic industries

All basic industries

$\begin{array}{ll}\text { Employment } & \text { Earnings } \\ & \frac{1980}{1970} \quad 1980\end{array}$

(Percent of economic base)

$\begin{array}{rrrr}26.8 & 32.0 & 37.3 & 40.2 \\ 19.8 & 16.2 & 21.0 & 18.5 \\ & & & \\ 8.2 & 11.0 & 4.5 & 6.9 \\ 18.3 & 9.9 & 10.4 & 4.0 \\ 5.8 & 6.6 & 5.3 & 7.1 \\ 0 & 5.8 & 1.4 & 10.4 \\ 6.3 & 5.3 & 5.7 & 4.0 \\ .1 & 2.5 & 3.5 & 2.5 \\ 2.3 & 2.0 & .9 & 1.8 \\ 2.4 & 1.8 & 3.4 & 2.5 \\ 2.3 & 1.6 & 1.0 & 0\end{array}$

92.3

94.7

94.4

97.9

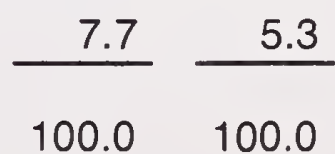

5.6

2.1

1.8

.5

$100.0 \quad 100.0$ 
Geographical Importance of the Region's Forest Products Industry
Nevertheless, the forest products industry remained the second largest segment of the State's economic base. As in Oregon, the contribution of the forest products industry to the State's economic base was underestimated because some selfemployed workers were engaged in logging and hauling and some Federal employees were involved in forest management activities.

Federal military and civilian employment declined in importance between 1970 and 1980 , reflecting the end of the Vietnam war. Construction of several nuclear powerplants stimulated growth of the construction industry during the late 1970's and early 1980's. Subsequent mothballing of several powerplants led to large layoffs in the construction industry.

The contribution of the forest products industry to the local economic base varies considerably between sub-State districts (see appendix 2 for a listing of counties by district). Generally speaking, the forest products industry is more important in western Oregon and western Washington than in the eastern half of the region. In Oregon, for example, the forest products industry accounts for almost two-thirds of the Roseburg area's economic base (that is, the industries that produce goods or services for export to areas outside the sub-State districts), but for less than 10 percent in the Burns area. Likewise, the forest products industry is much more important in southwestern Washington than elsewhere in the State. The Pacific Northwest's dependency on the forest products industry decreased in most subState districts between 1970 and 1980. Despite these changes, diversification of the economic base proceeded slowly in the nonmetropolitan areas. In most nonmetropolitan areas in western Oregon and western Washington, the forest products industry will likely continue to remain the major source of export dollars for the foreseeable future. 


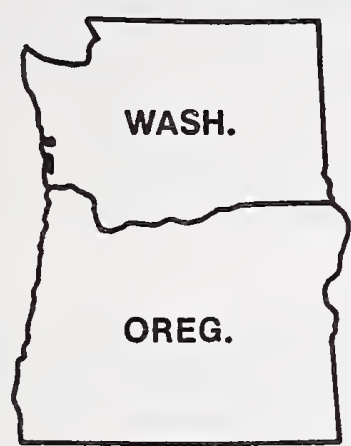

LEGEND

Dependency index, 1980 (based on employment)

- no dependency

- less than 10

-10 to 20

-21 to 35

-36 to 50

- greater than 50

Dependency - change, $1970-80$

no change

increase

decrease

Number designates sub-State planning and development districts (see appendix 2).

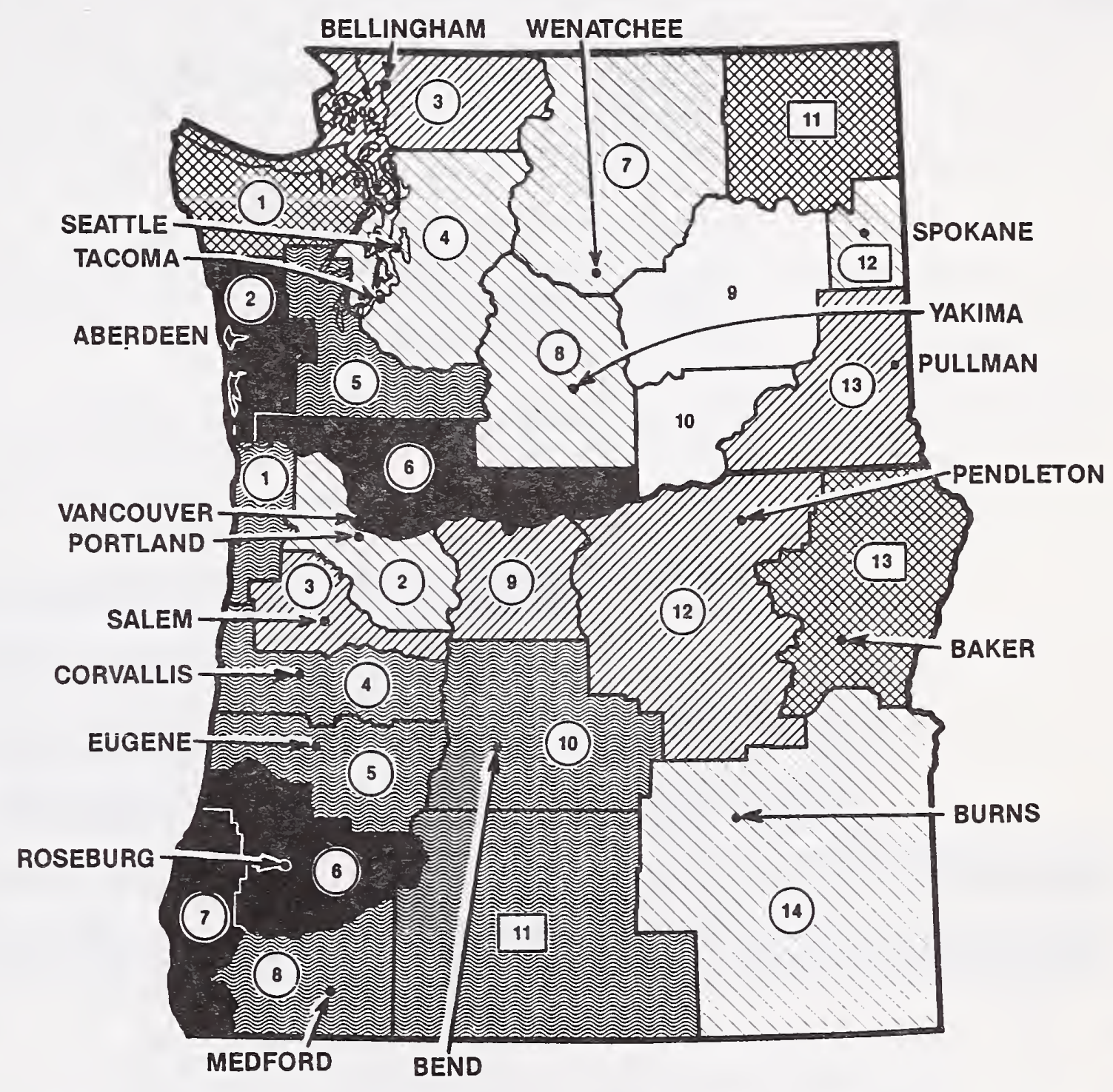

Source: Sub-State estimates for 1970 and 1980 were derived from unpublished county data series provided by the U.S. Department of Commerce, Regional Economic Information System, Bureau of Economic Analysis, Washington, DC; and from the U.S. Department of Commerce, Bureau of the Census, "County Business Patterns." The numbers in the squares and circles used to designate sub-State districts correspond to the geographical classification of counties as shown in appendix 2 . 
Composition of the Region's Forest Products Industry

In 1980, lumber and wood products accounted for the largest share of the workers employed by the forest products industry in the Pacific Northwest. It also had the largest share of earnings. The paper and allied products industry accounted for a larger proportion of total employment and earnings in the forest products industry in Washington than in Oregon. In both States, wood furniture manufacturing was much less important than lumber and wood products or paper and allied products.

Between 1970 and 1980, total employment in the forest products industry changed slightly. In 1980, the Pacific Northwest accounted for 9 percent of the Nation's forest products industry employment and 11 percent of the earnings compared with 9 and 10 percent in 1970.

Growth in employment in lumber and wood products was counterbalanced by the decline in employment in other forest products industries. The growth rate of earnings in the forest products industry in the region (32 percent) exceeded the average for all U.S. industries (27 percent). The increase in earnings in the paper and allied products and the lumber and wood products overshadowed the decrease in earnings of wood furniture manufacturing employees.

\section{PNW \\ 1980 employment}

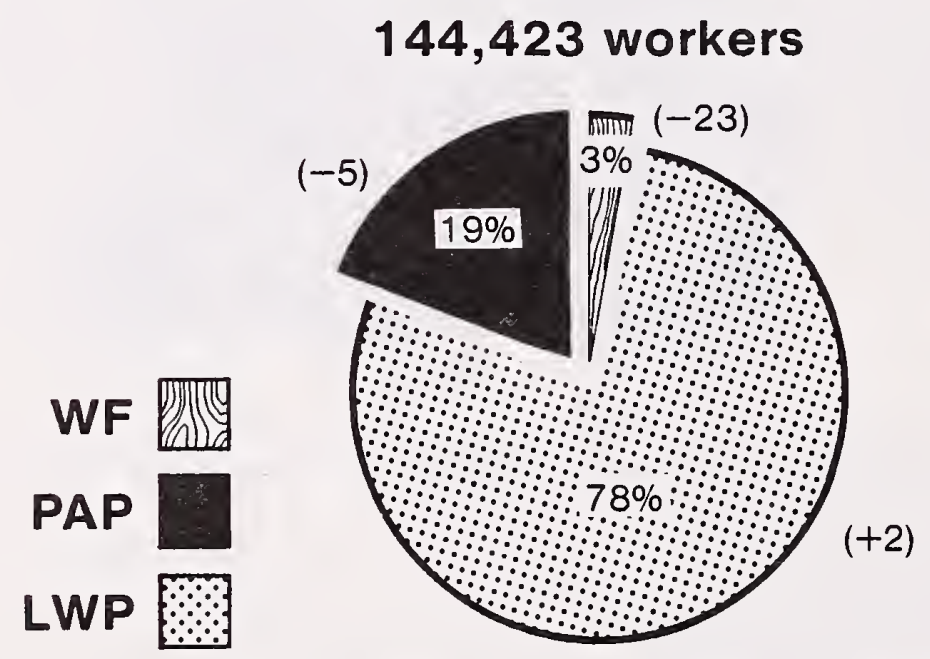

\section{PNW 1980 earnings}

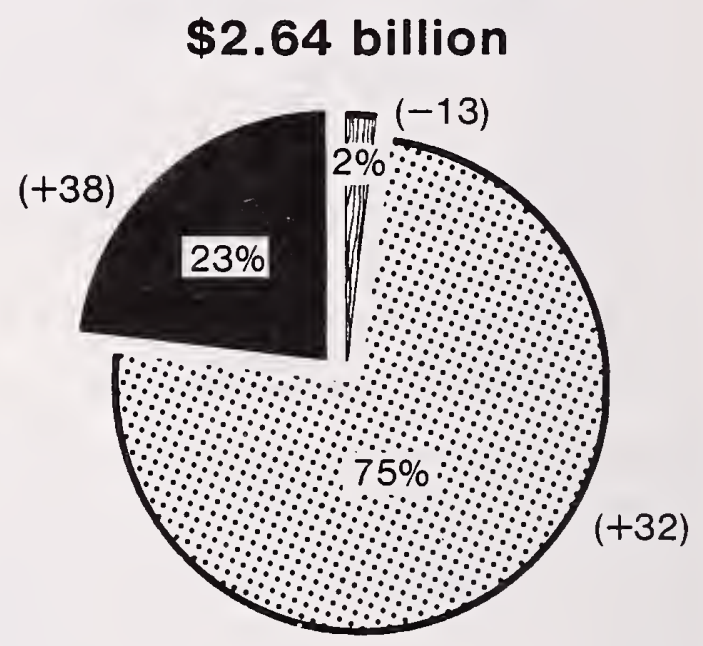

Numbers in parentheses show percentage of change from 1970 to 1980 . 
Average Annual Wage and Salary Earnings per Worker
Average annual 1980 earnings per worker in paper and allied products were significantly greater than in lumber and wood products or in wood furniture. This difference is mainly the result of higher average skills, more capital investment per worker, and more union membership in the paper and allied products industry. Earnings per worker in wood furniture were just over one-half those for paper and allied products and significantly below the average for all forest products industries in the United States $(\$ 14,47)$.

With the exception of wood furniture manufacturing, the average income of all forest products industry workers in the Pacific Northwest exceeded the average for the Nation. Furthermore, between 1970 and 1980 earnings in the lumber and wood products and the paper and allied products segments increased at a much higher rate than the average earnings for the Nation's forest products industry (19 percent).

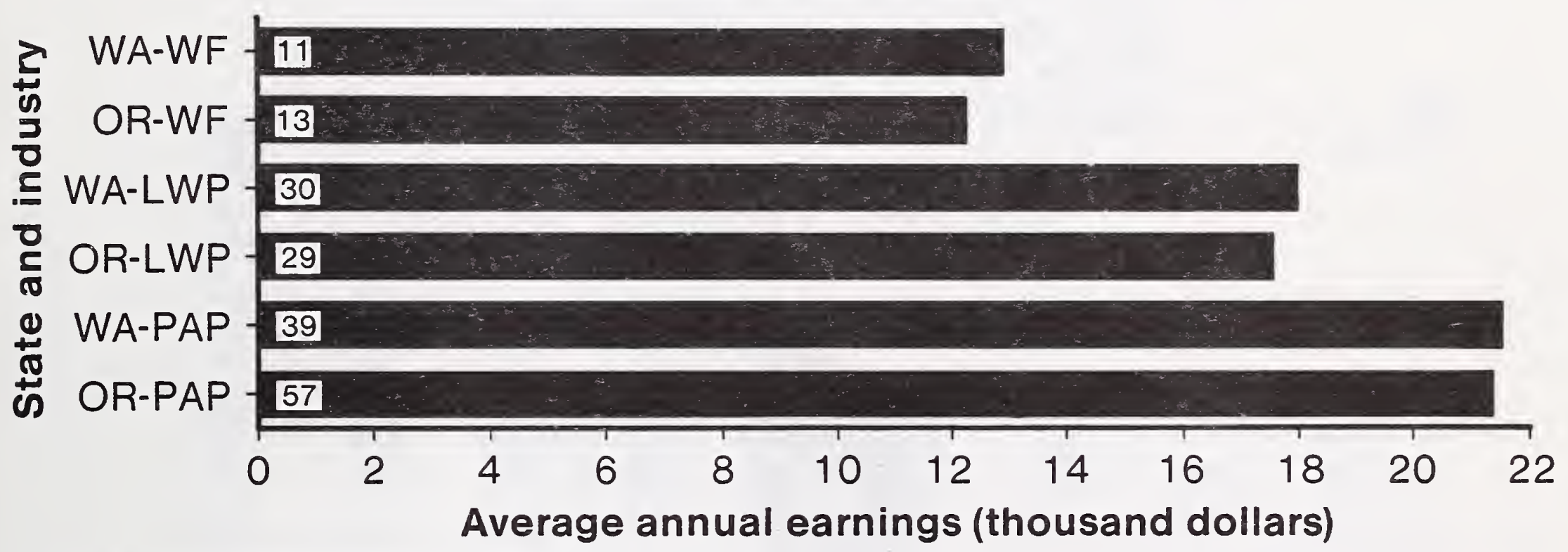

Numbers in bars show percentage of change from 1970 to 1980 . 
Value Added by the Forest Products Industry 4

Value added by manufacturing is equal to the value of shipments less the cost of materials, parts, supplies, fuel, goods purchased for resale, electric energy, and contract work. Unlike value of shipments, value added includes only the economic contributions of the forest products industry. Consequently, value added by manufacturing is a better monetary gauge of the relative economic importance of a particular manufacturing activity than are shipments. In 1982, lumber and wood products accounted for nearly three-fourths of the $\$ 1.5$ billion of the value added by Oregon's forest products industry and for half of Washington's $\$ 1.4$ billion of value added. With the exception of wood furniture in Washington, value added by the region's forest products industry declined significantly between 1977 and 1982 . The decline in value added came after it reached a historic high in 1977. In 1982 the forest products economy was in the midst of the Nation's worst recession since World War II.

4) The Census of Manufactures is conducted every 5 years (for example, 1972, 1977, and 1982); consequently, data for value added were not available for 1970 and 1980. Value added for 1982 reflect a greater downturn in the forest products industry than do the 1980 data for employment and earnings.

\section{Value added by Washington FPI, 1982}

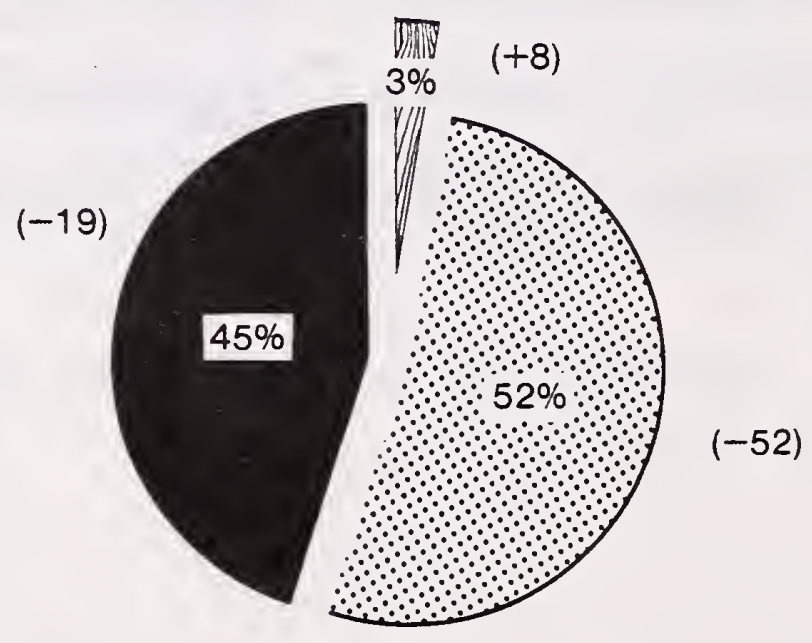

Value added by Oregon FPI, 1982

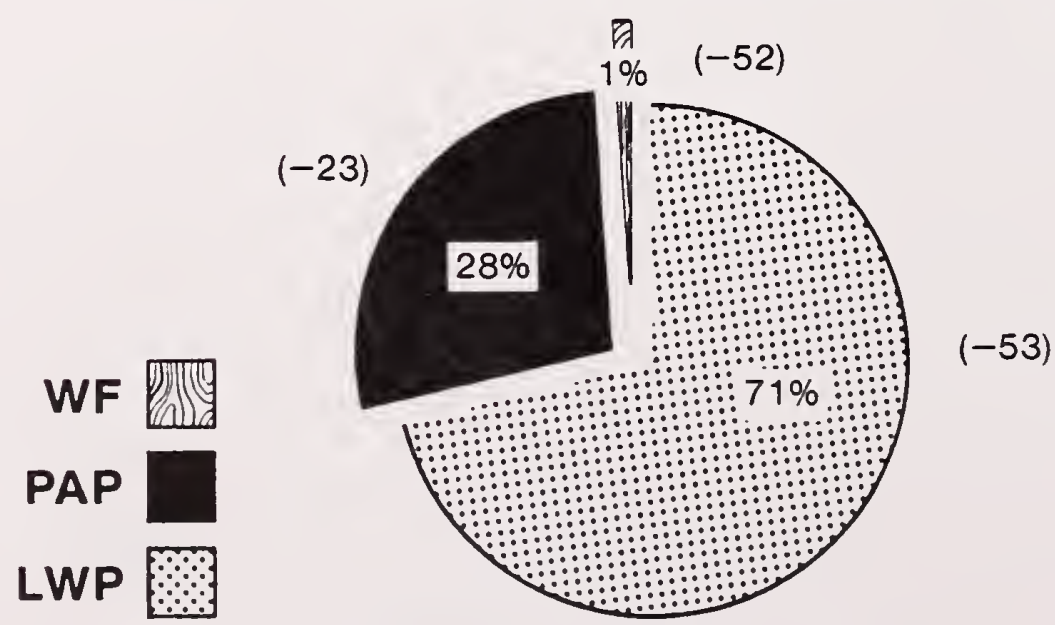

Numbers in parentheses show percentage of change from 1977 to 1982. 
Increases in profits are necessary for an industry to remain competitive in the marketplace. Value added minus payrolls (VAMP) is a measure of industry profits before taxes per worker hour; it represents the return to capital investment and entrepreneurship (see appendix 1, tables 4 and 5, for VAMP measures for the forest products industry, by subregions).

Paper and allied products is more capital intensive than are the other segments of the forest products industry. Not surprisingly, therefore, its profits per worker hour are the highest in the industry. During the mid-1970's, this segment also exhibited a larger gain in profits than either lumber and wood products or wood furniture. In 1977 , profits for lumber and wood products were much higher than for wood furniture. During the recessions of the early 1980's lumber and wood products continued to experience relatively high labor and operating costs while demand was drastically curtailed. Consequently, by 1982 its profits dropped below those for wood furniture. Profits per worker hour in the wood furniture segment increased between 1977 and 1982.

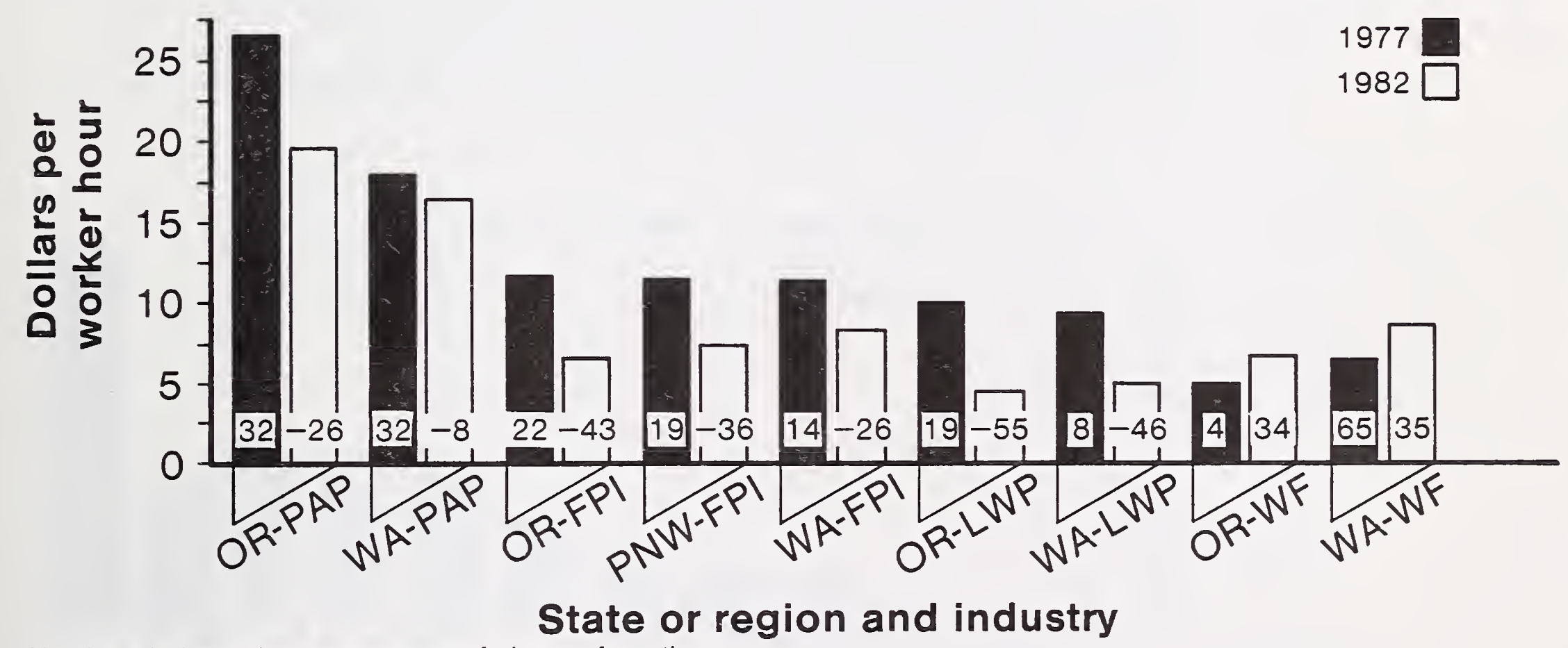

Numbers in bars show percentage of change from the previous census year. 
Comparing the Forest Products Industries of the Pacific Northwest and the South Importance of the Industry
In 1980, 9 of 13 States in the South manufactured forest products in excess of statewide needs. Florida, Kentucky, Oklahoma, and Texas were not self-sufficient with respect to forest products; that is, these States imported more forest products than they exported. Consequently, on net balance, their respective forest products industries were not part of their economic base.

The forest products industry accounts for a much smaller portion of the economic base of the South than that of the Pacific Northwest. Arkansas was the most timber dependent of the Southern States. Its forest products industry accounted for 16.6 percent of economic base employment, or approximately one of six employees. The State of Washington is nearly as timber dependent as Arkansas, but in Oregon the forest products industry accounted for about two of every five basic jobs. Without the forest products industry, economic activity in many nonmetropolitan communities in the Pacific Northwest would be much less.

Unlike Washington or Oregon, several Southern States were more timber dependent in 1980 than in 1970. In the South, however, most nonmetropolitan areas are more diversified than their counterparts in the Pacific Northwest. Consequently, the growing importance of the forest products industry in the South during the 1970 's, although welcome, was not as noticeable as the decreasing importance of the forest products industry in the Pacific Northwest.

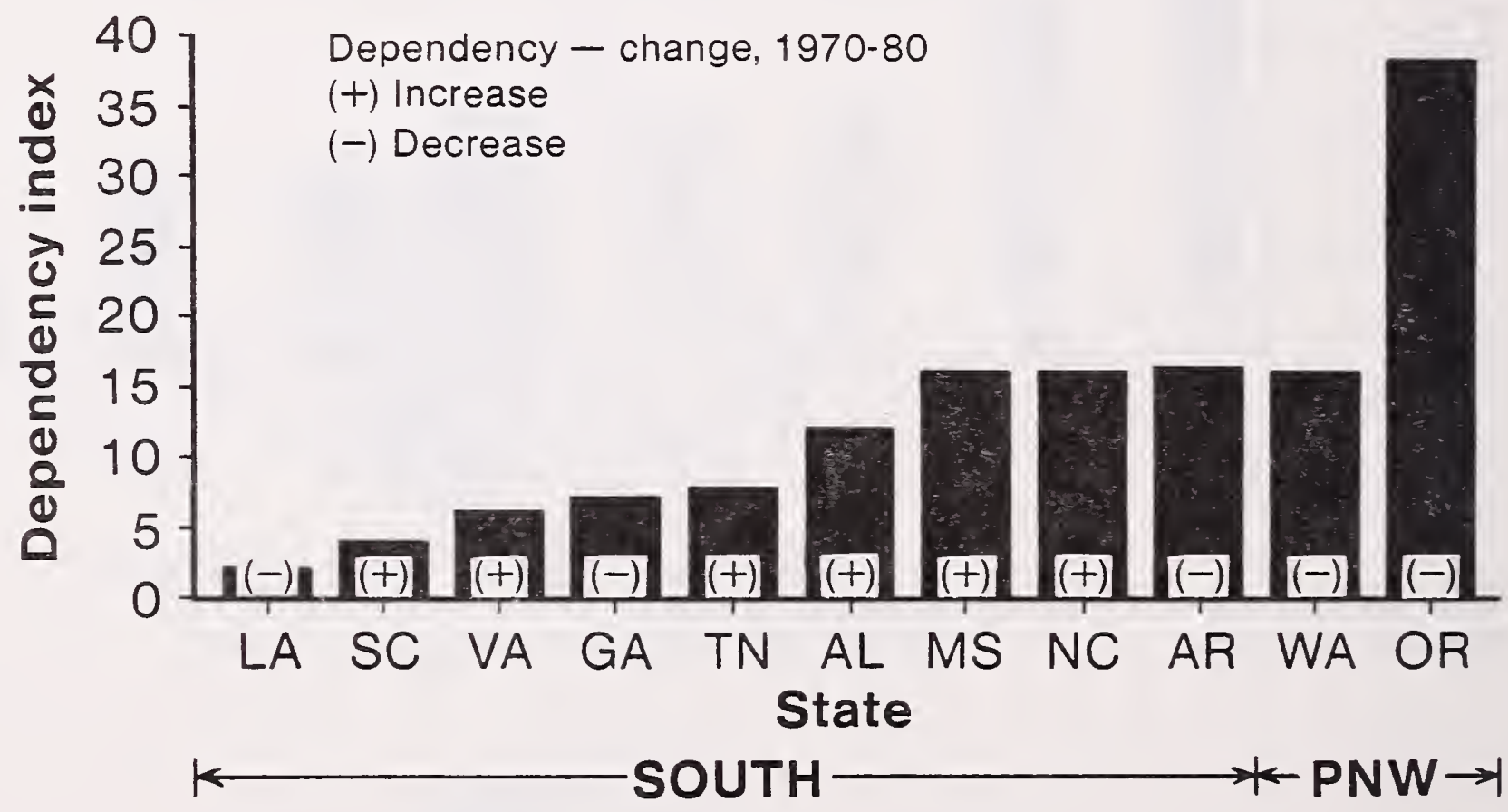




\section{A Comparison of Industry Composition}

The forest products industry includes both primary and secondary processing. Most primary manufacturing activity is located near the raw material sources in rural areas, whereas a significant portion of secondary processing is near markets for forest products in large metropolitan areas. Examples of the latter kinds of processing include the fabrication of kitchen cabinets, structural wood members, paperboard containers and boxes, and other miscellaneous paper products.

Together, the Pacific Northwest and the South account for slightly less than half the employment (47 percent) and earnings (45 percent) in the Nation's forest products industry. The South accounts for a much larger share of employment and earnings ( 38 and 34 percent, respectively), of the Nation's totals than the Pacific Northwest ( 9 and 11 percent).

The composition of the South's forest products industry is more evenly distributed between the three segments than it is in the Pacific Northwest and the rest of the Nation (see illustration on page 14). In the Pacific Northwest, for instance, lumber and wood products accounts for three-fourths of the industry's earnings and for a slightly higher percentage of its employment. Unlike the South, in the Pacific Northwest wood furniture is barely represented. 


\section{0 employment}

PNW - 144,423 workers

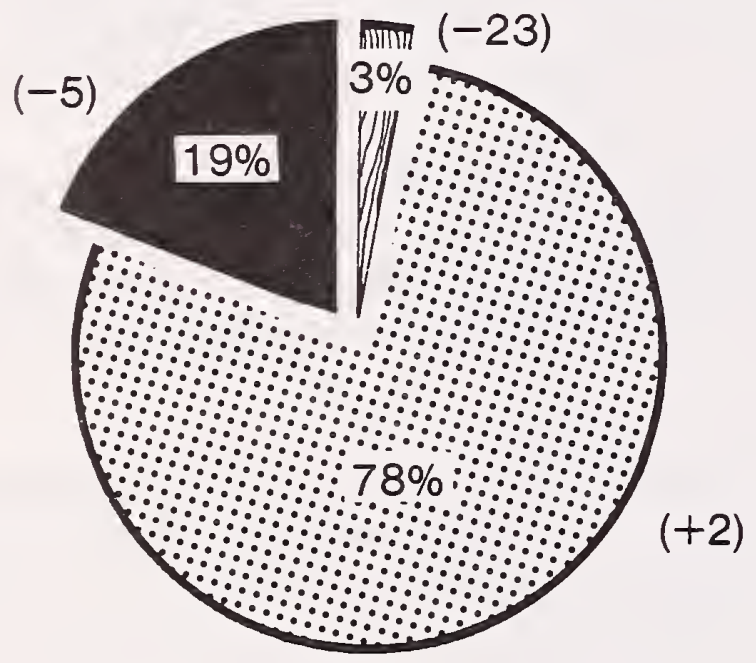

South $-620,567$

$(+13)$

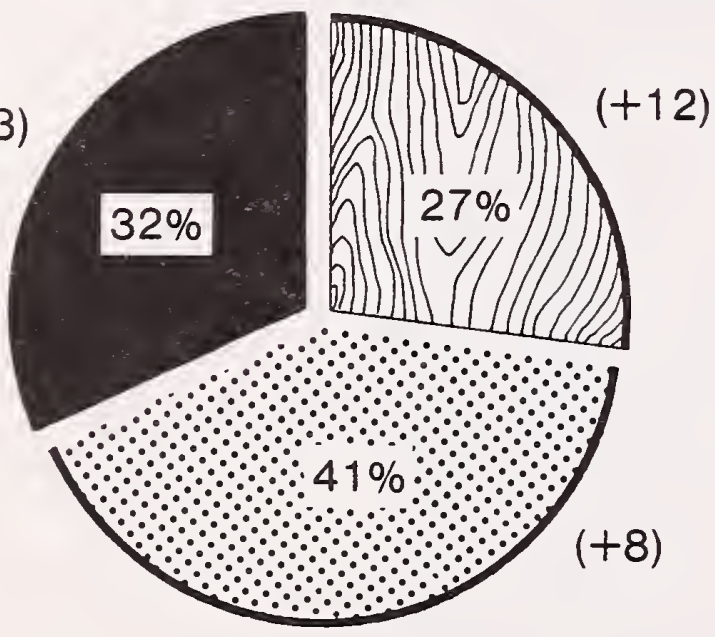

Rest of Nation $-869,381$

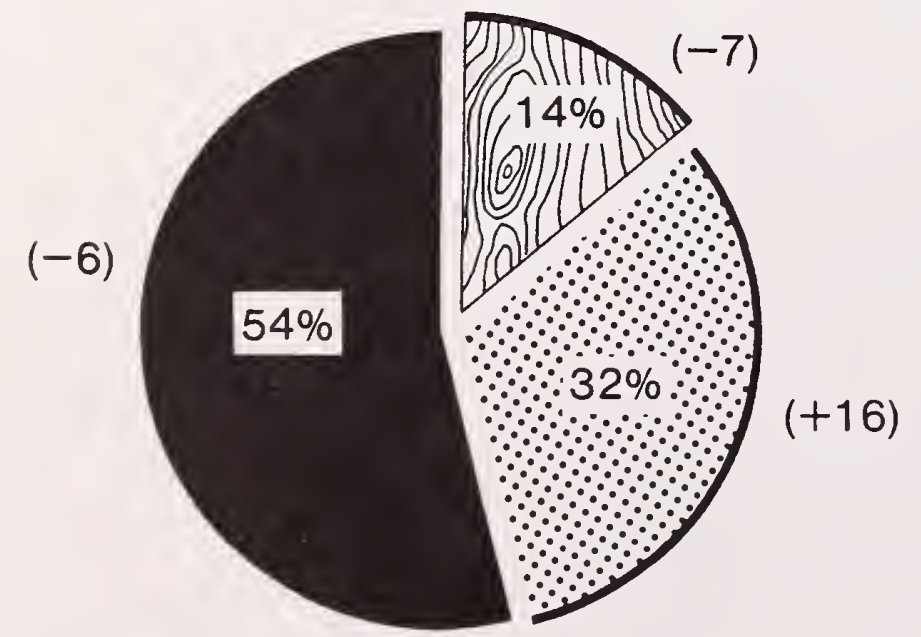

Numbers in parentheses show percentage of change from 1970 to 1980 . Earnings are expressed in constant 1977 dollars.

\section{0 earnings}

PNW $-\$ 2.64$ billion
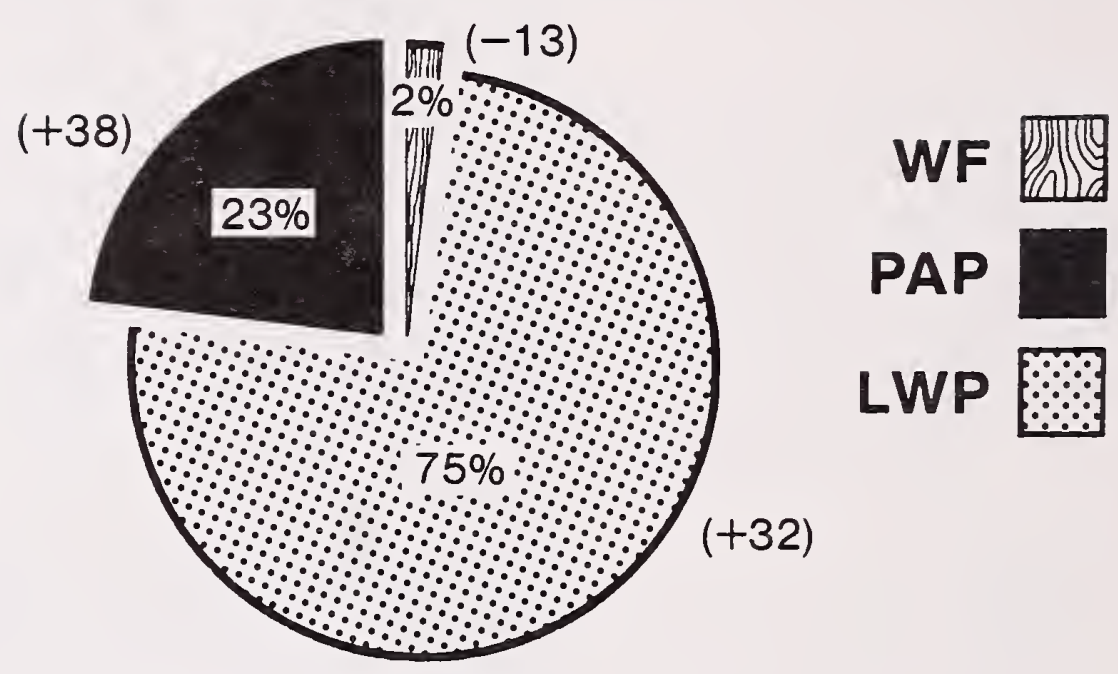

South $-\$ 7.96$ billion

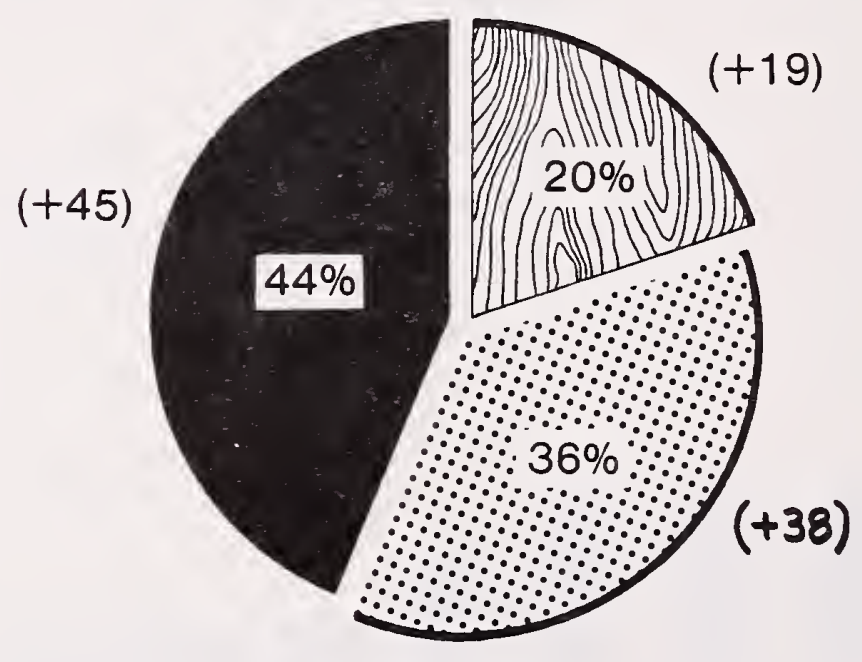

Rest of Nation - \$13.04 billion

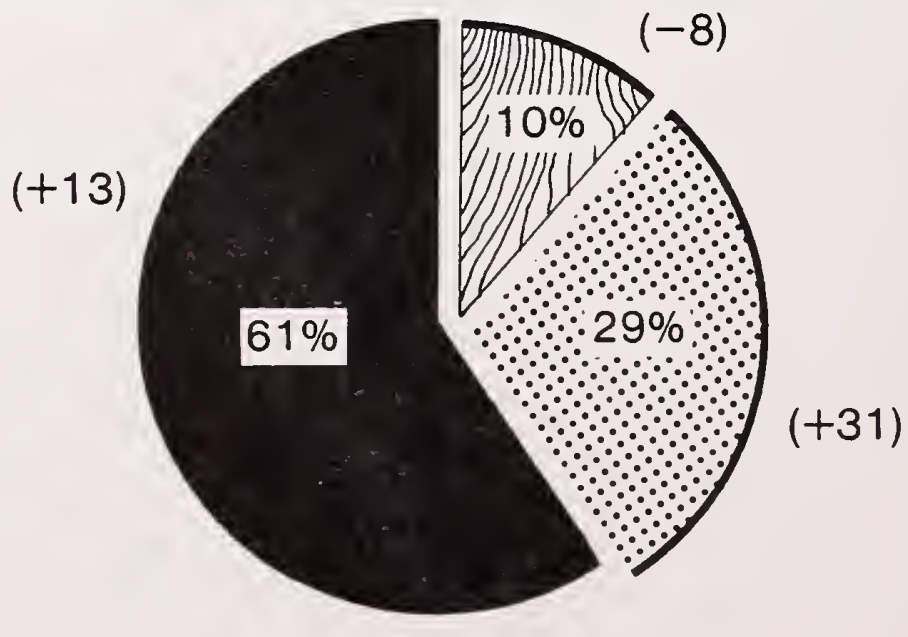


Between 1970 and 1980, employment in the Nation's forest products industry increased by 4 percent. Change in employment, however, varied from State to State. For example, employment decreased in Oregon but increased in Washington. On balance, therefore, the region's employment changed little between 1970 and 1980. With the exception of Arkansas and Louisiana, employment in the forest products industry in each of the Southern States grew faster than the U.S. average of 4 percent. Employment in the forest products industry in Oklahoma and Texas grew faster than the national average of 22.3 percent for all industries.

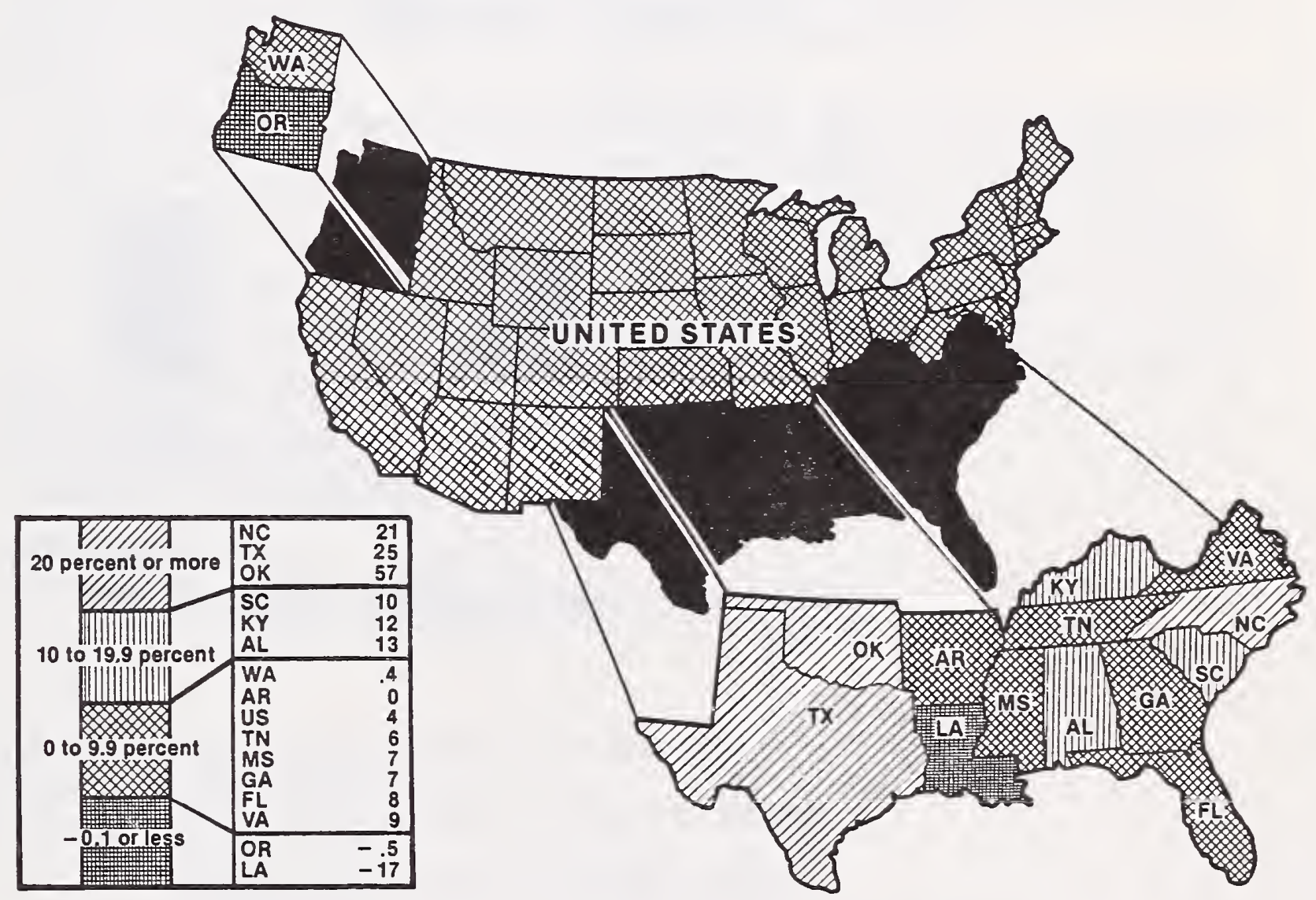


Average Annual Wage and Salary Earnings per Worker
Average annual earnings per worker in the forest products industry differed significantly by region in 1980 . Earnings are generally lower throughout the South than in the Pacific Northwest. In fact, in 1980 average annual earnings in all three segments of the South's forest products industry were lower than in the Pacific Northwest. With the exception of lumber and wood products, average annual earnings increased faster in the Pacific Northwest than in the South.

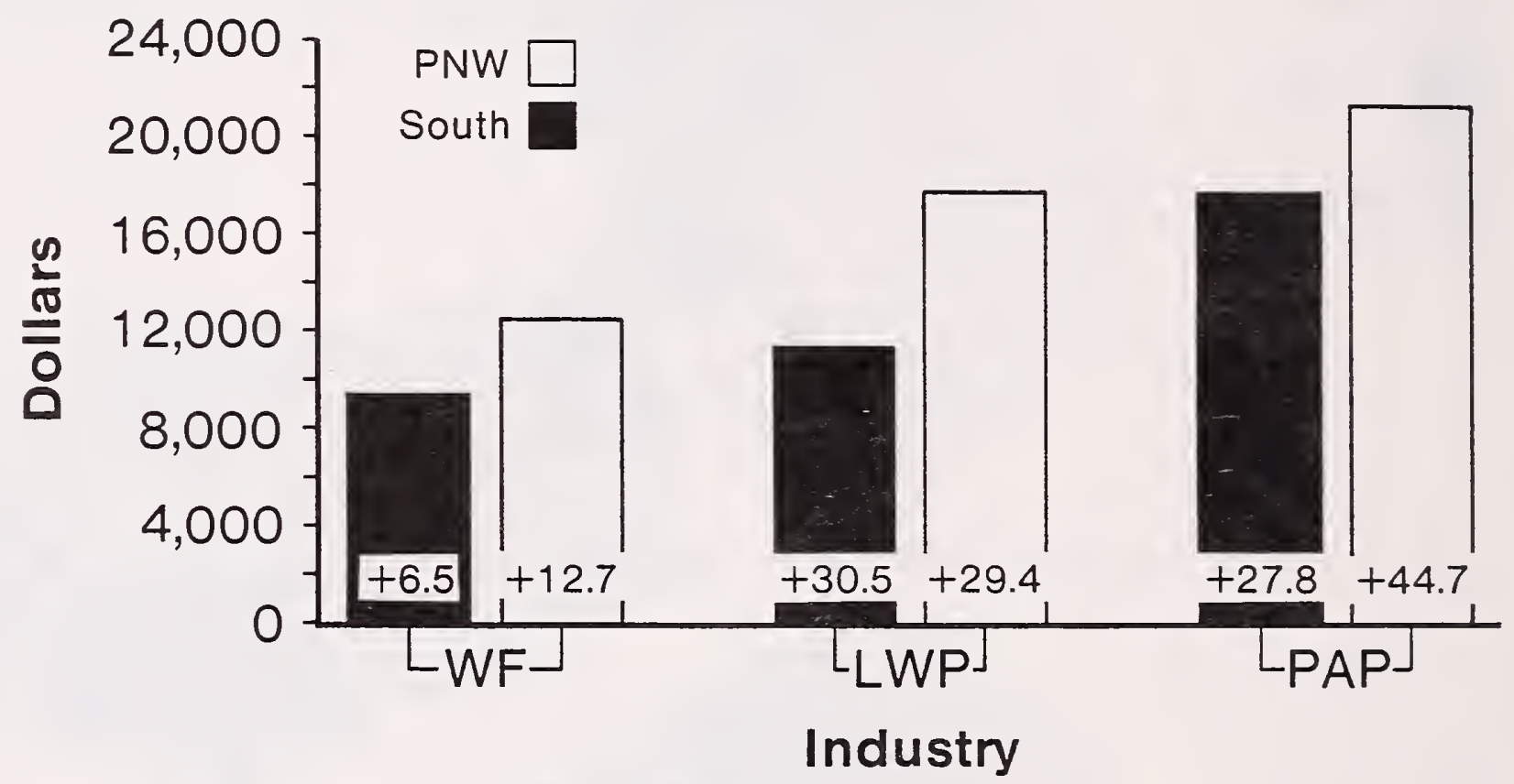

Numbers in bars show percentage of change from 1970 to 1980 . 


\section{Shift in Shares of Employment and Earnings}

The shift in shares of employment and earnings indicates how much more or less employment and earnings a region's forest products industry would have had in 1980 had it grown at the national average rate between 1970 and 1980.5 For example, the Pacific Northwest had approximately 11,000 fewer employees in 1980 than it would have had if its forest products industry had grown at the national rate (see illustration on page 18). Conversely, the South had 35,000 more employees than it would have had if its forest products industry had grown at the national rate.

Between 1970 and 1980, shares of earnings in the forest products industry increased in both the South and the Pacific Northwest. Meanwhile, the rest of the Nation had a smaller share of both earnings and employment.

Increased shares of employment and earnings reflect the comparative advantage of the forest products industry in the South over that in the Pacific Northwest. Several factors (for example, lower labor costs, lower raw material costs, and closer markets) might account for a region's comparative advantage, although adverse trends in one factor need not reduce a region's advantage. In the South, for instance, increasing labor costs need not adversely affect its comparative advantage if costs are increasing faster elsewhere, or if either increased capital or labor productivity offsets higher labor costs.

5/ The regional shift in share of employment

for industry $i=\left[\frac{e m p_{i}^{\prime}}{e m p_{i}}-\frac{E M P_{i}^{\prime}}{E M P_{i}}\right]$ empi;

where,

$\begin{aligned} E P_{i}= & \text { employment in industry } \mathrm{i} \text { in Nation at begin- } \\ & \text { ning of period; } \\ \text { EMP' }_{\mathrm{i}}= & \text { employment in industry } \mathrm{i} \text { in Nation at end of } \\ & \text { period; } \\ \text { empi }= & \text { employment in industry } \mathrm{i} \text { in region at begin- } \\ & \text { ning of period; } \\ \text { emp'i }= & \begin{array}{l}\text { employment in industry } \mathrm{i} \text { in region at end of } \\ \text { period. }\end{array}\end{aligned}$

Note: The components of the shift in share of earnings were derived in a similar fashion. 

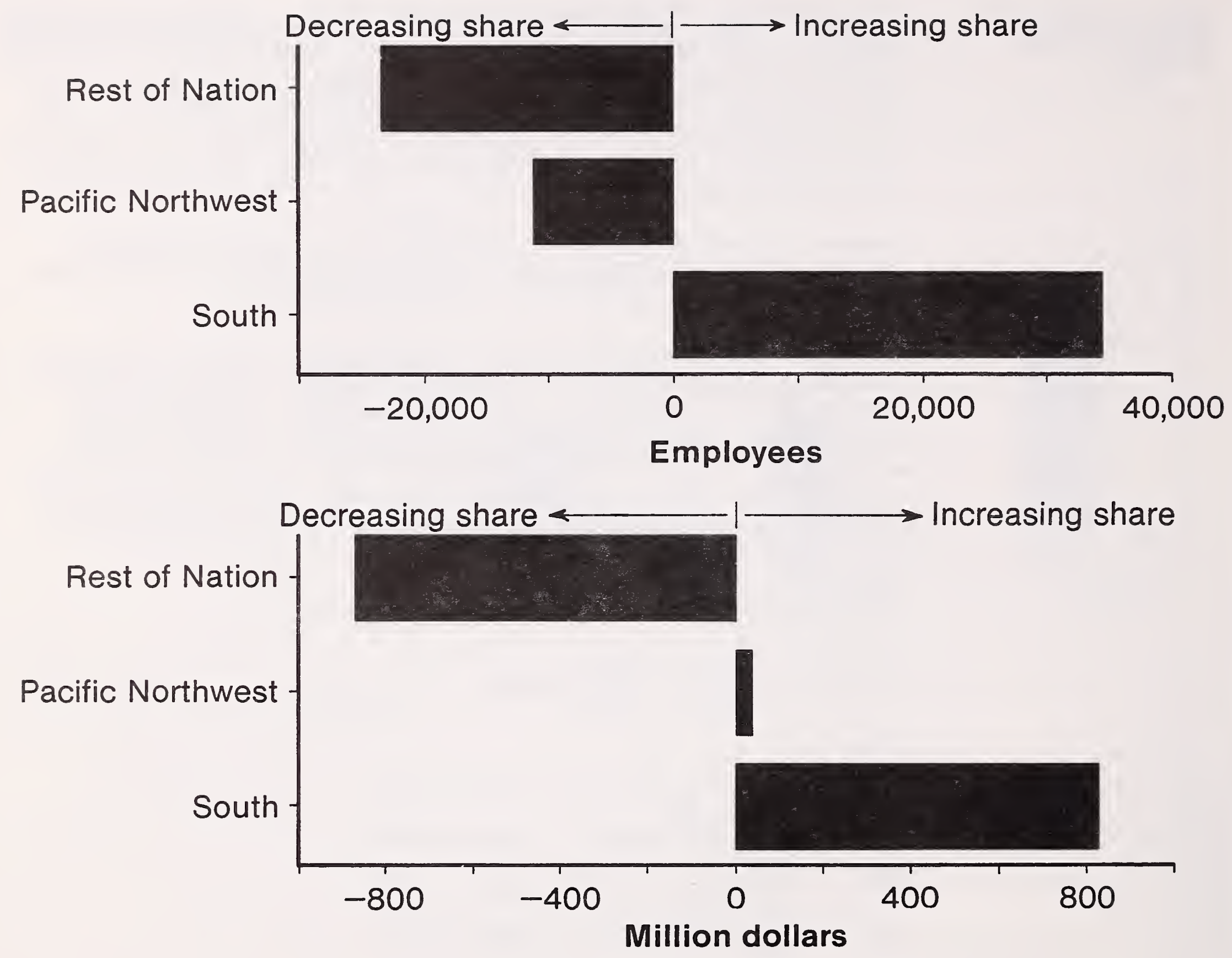
The Diversity of the South's Timber-Based Economy
The various segments of the forest products industry are not uniformly distributed throughout the South. The wood furniture segment, for example, is centered in the South Atlantic area, and the southern pine plywood industry is centered in the mid-South. Paper and allied products dominates the forest products industry in the East South Central States. Because of the proximity to several large and rapidly growing metropolitan areas, secondary processing is a larger segment of the forest products industry in the West South Central area than elsewhere in the South.

The southern pine plywood industry started in the mid-South and eastern Texas. The first investors were attracted here, in part, because of the availability of large tracts of mature timber that could be held in fee ownership (Cleaves and O'Laughlin 1985).

Wood furniture manufacturing is concentrated in North Carolina, whereas paper and allied products and lumber production can be found throughout the South. In 1982, paper and allied products accounted for 70 percent of the value added by the forest products industry in the East South Central area. Elsewhere in the South it accounted for slightly more than half of the value added.

Plywood and lumber mills compete for large size timber. In fact, the development of the southern plywood industry during the last two decades caused many of the South's more labor intensive sawmills to close.

High energy and labor costs in the Northern States prompted industrial growth and development in the Sunbelt. This led to significant growth in lumber markets in Southern States-such as Florida, Georgia, and Texas-that have large metropolitan areas.

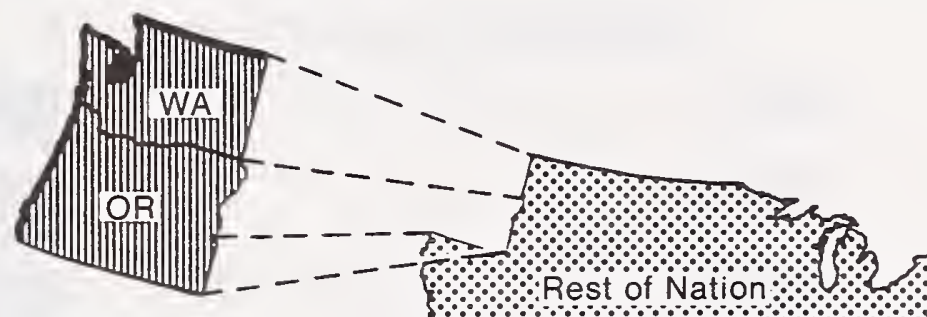

Pacific Northwest WA-OR

West South Central OK-TX

Mid-South AR-LA-MS

East South Central KY-TN-AL

South Atlantic VA-NC-SC-GA-FL

Rest of Nation

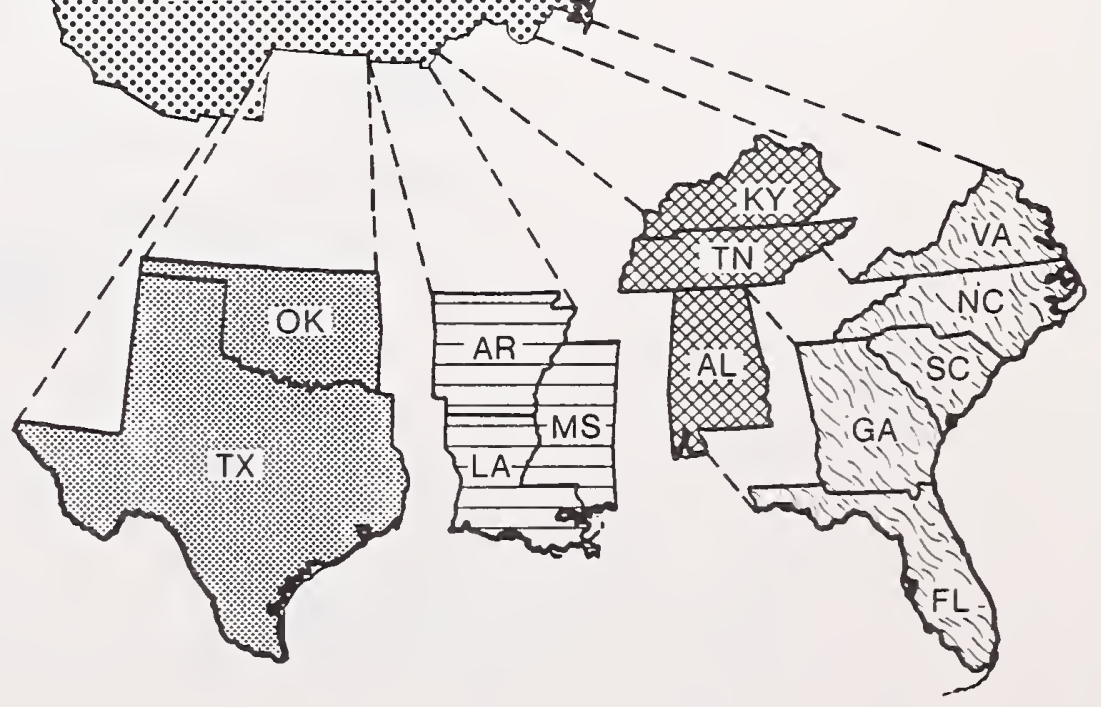


The Resemblance of the Pacific Northwest to the Mid-South
Most of the Southern States increased their share of the Nation's forest products employment between 1970 and 1980. The exception was in the mid-South, where the trend in employment resembled that in the Pacific Northwest. Actually, the share of employment in the mid-South began to drop at the beginning of the decade, whereas the share of the employment in the Pacific Northwest continued to increase until 1975.

During this period, both the mid-South and the Pacific Northwest increased their shares of FPI earnings, but not as much as the rest of the South.

\section{Shift in employment, 1970 to 1980}

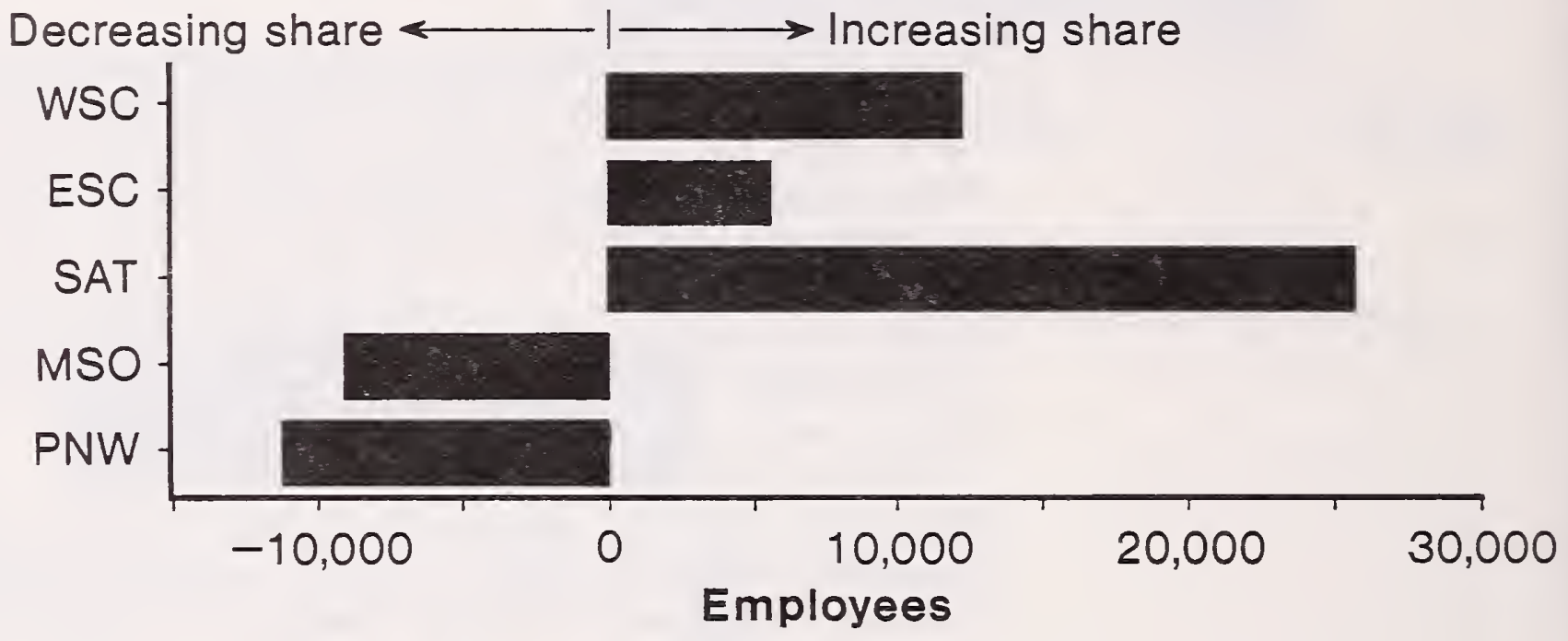

Shift in earnings, 1970 to 1980

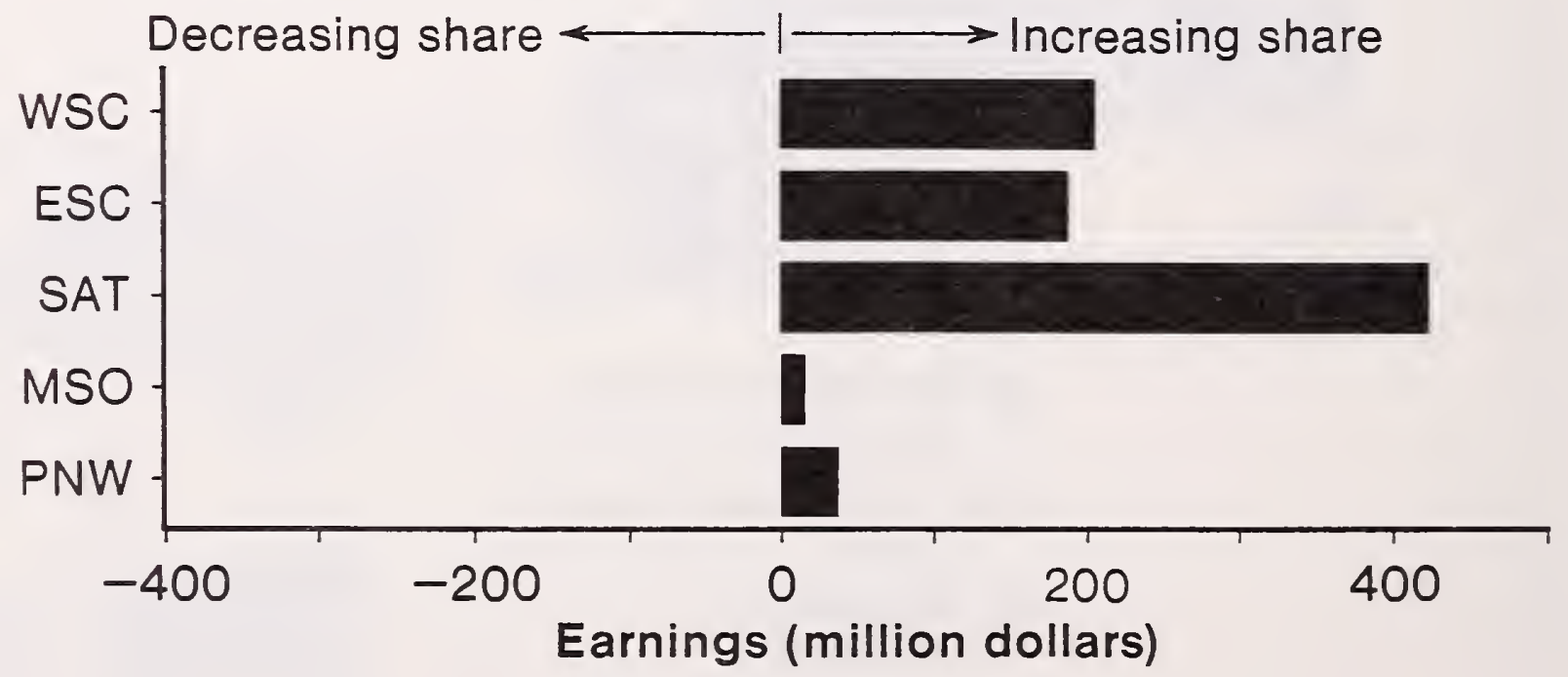




\section{Shift in Shares of Employment and Earnings, by Industry Segment}

In the Pacific Northwest, most of the change in shares of employment was confined to the lumber and wood products segment (including plywood and sawmills). Elsewhere in the Nation, paper and allied products accounted for most of the change. Paper and allied products also accounted for the major shift in shares of earnings in the forest products industry. Both the South and the Pacific Northwest increased their respective shares at the expense of the rest of the Nation (RON).

The disaggregated trends, like those for the entire forest products industry, reveal similarities between the Pacific Northwest and the mid-South. Between 1970 and 1980 , both regions experienced a decline in their share of employment in the lumber and wood products and paper and allied products segments. Furthermore, both areas lost shares of lumber and wood products earnings while gaining shares of paper and allied products earnings.

The rest of the Nation accounted for most of the increase in shares of employment in the lumber and wood products segment. Most of this gain was associated with secondary softwood lumber processing (such as millwork and structural wood members) near large metropolitan areas. The RON's overall decline in shares of employment in the forest products industry resulted from substantial shifts in the paper and allied products and wood furniture segments.

Overall, the Southern States had a smaller share of lumber and wood products employment in 1980 than in 1970. The West South Central area, however, increased its share. The growth of secondary processing of lumber and wood products near several large and rapidly growing metropolitan areas in Texas and Oklahoma accounted for the difference. 


\section{Shift in employment, 1970 to 1980}

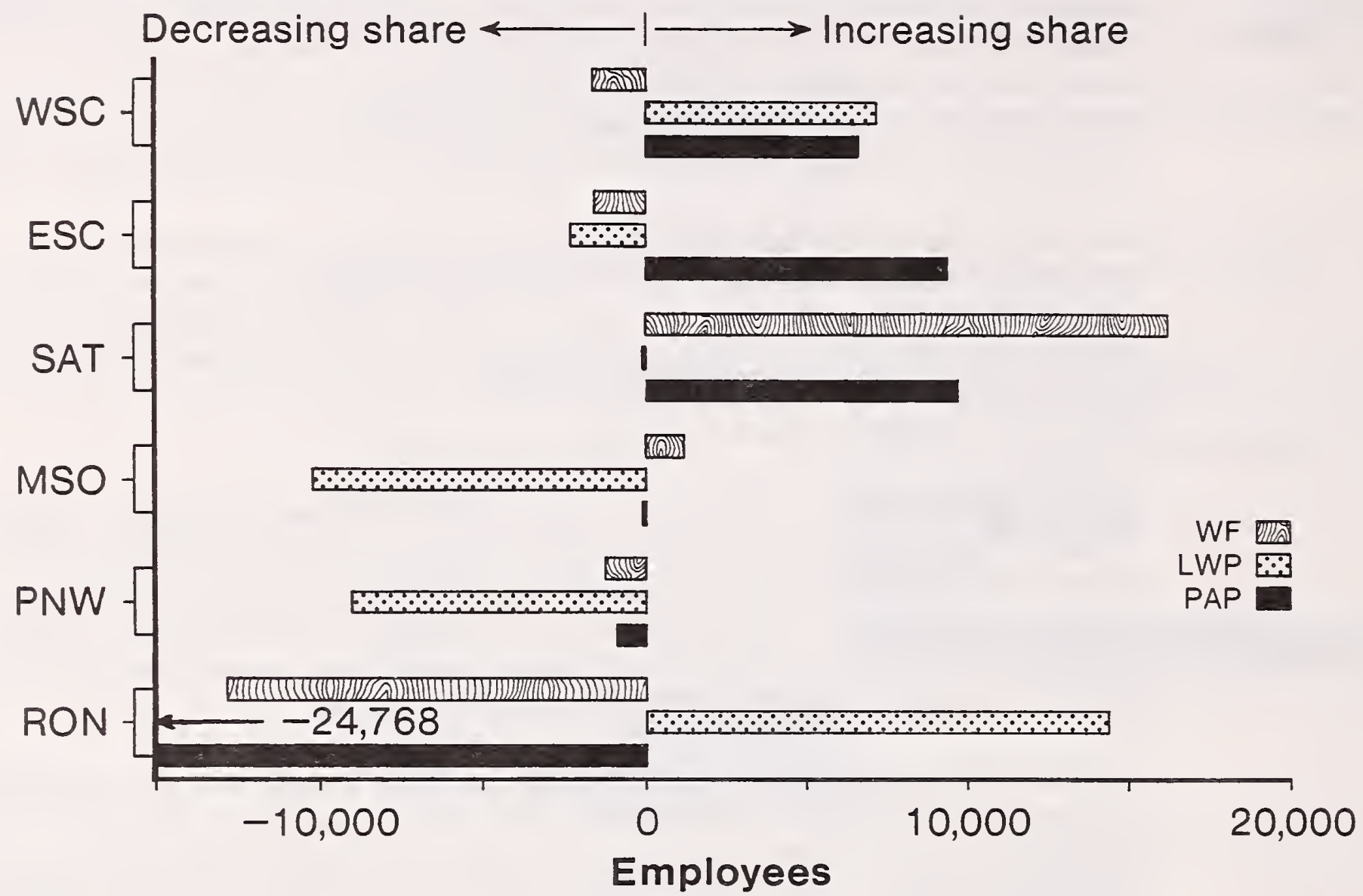

\section{Shift in earnings, 1970 to 1980}

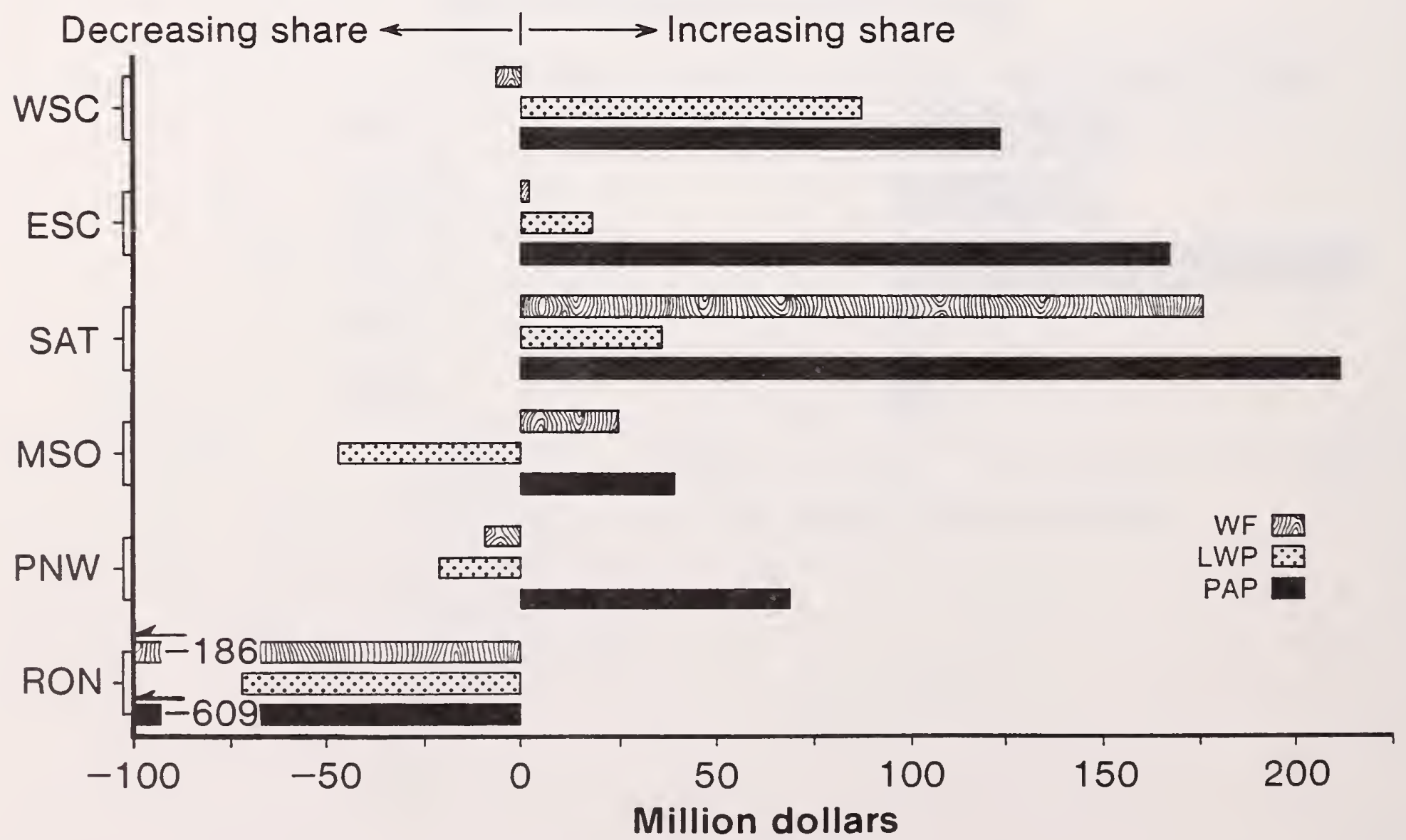


Changes in Value

Added by the Forest

Products Industry
Between 1972 and 1977, the increase in value added was fairly uniform in the Pacific Northwest and the South. The exception was the West South Central area. The decline after 1977, however, was much more substantial in the mid-South and the Pacific Northwest than elsewhere in the South.

In both the Pacific Northwest and the South, lumber and wood products accounted for most of the decrease in value added between 1977 and 1982. This decline reflected the sharp drop in the Nation's homebuilding activity. During this interval, demand for paper products held steady, and value added by the South's paper and allied products increased. Meanwhile, however, value added by paper and allied products in the PNW declined.

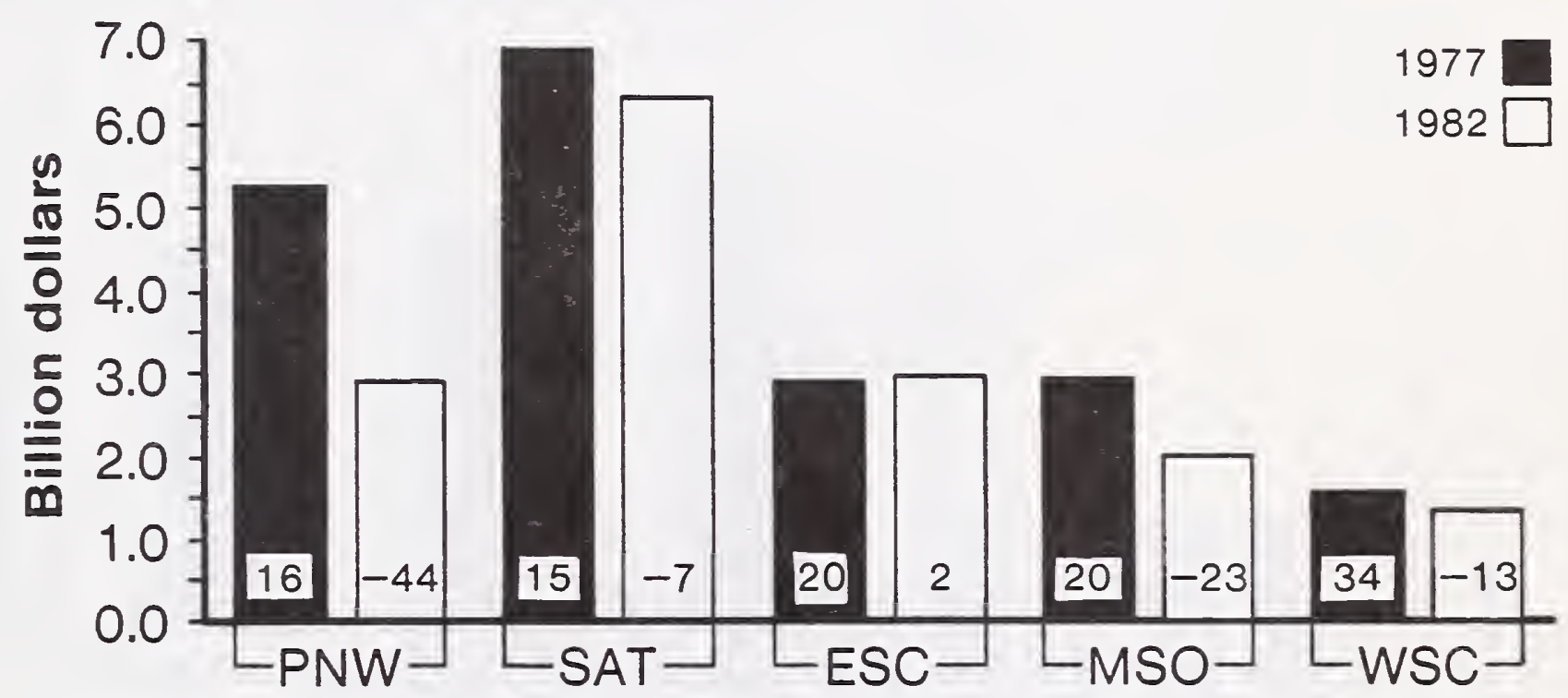

Numbers in bars indicate the change in value added from the previous census year. 
Profits Decrease After the Collapse of the Housing Market
In 1977, profits before taxes were higher in the Pacific Northwest than throughout the South. Between 1972 and 1977, however, profits increased faster in the South than in the Pacific Northwest.

Because of the collapse of the housing market in the late 1970's and early 1980's, profits decreased in the Pacific Northwest and in most of the South between 1977 and 1982. The exception was the East South Central area where the increase in profits in the paper and allied products and wood furniture segments counterbalanced the decline in lumber and wood products.

Although the decline in profits in the forest products industry of the mid-South was not as substantial as in the Pacific Northwest, the decline-particularly for the lumber and wood products segment-was more than for most other areas of the South.

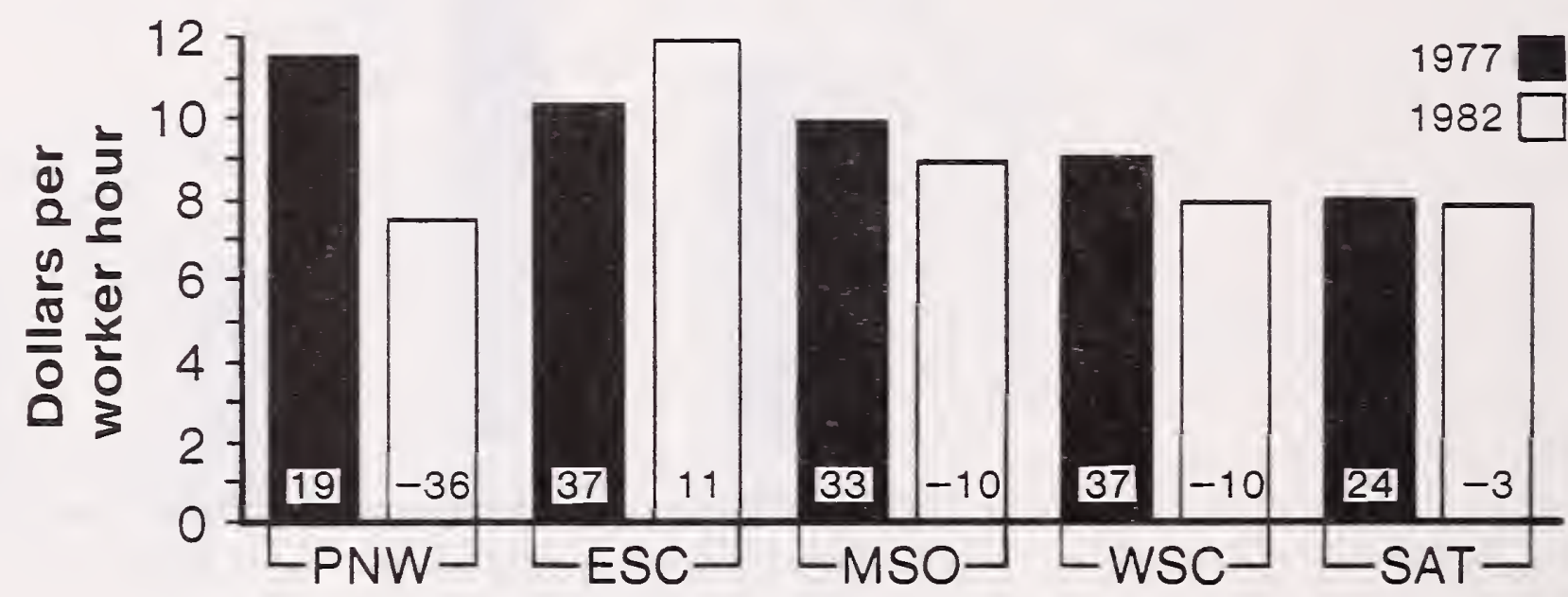

Numbers in bars indicate the change from the previous census year. 
Competition in the South
The South's increasing share of employment of the Nation's forest products industry did not result from the Pacific Northwest's declining share of employment in lumber and wood products but rather from shifts in the paper and allied products and the wood furniture segments. Between 1970 and 1980, these shifts had little bearing on what was happening in the Pacific Northwest because paper and allied products and wood furniture manufacturing were not very important compared with the region's production of lumber and wood products. Except for the decreasing shares in the Pacific Northwest and the mid-South, shifts in softwood lumber and wood products were mainly the result of secondary processing located near large and growing metropolitan areas.

The South's changing share of lumber and wood products employment reflects competition between sawmills and plywood mills for high quality sawtimber. Price data suggest that this competition was most intense in the mid-South and in eastern Texas where the southern plywood industry had its beginning. For example, during the 1977-79 upswing in the Nation's economy, the change and level of delivered prices for southern pine sawtimber were generally higher in the midSouth and in eastern Texas than elsewhere in the South.

\section{Index of average delivered price of southern pine sawtimber, 1977-79}

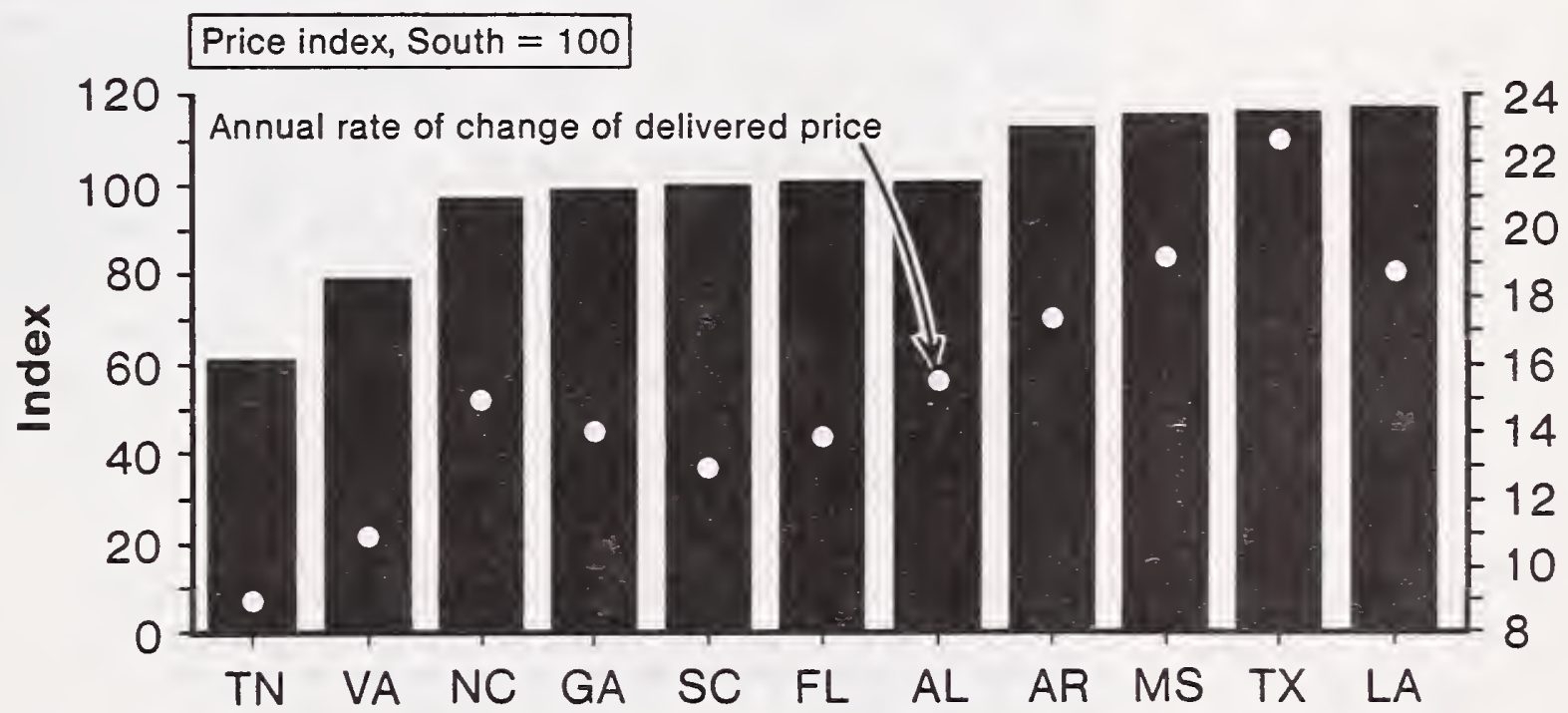

Source: Data Resources, Inc. (1984).

Competition caused many of the older, less efficient sawmills to close between 1970 and 1980. The mid-South, where price competition was most intense, had a higher rate of closures between 1970 and 1980 (U.S. Bureau of the Census 1971, 1981) than the rest of the South.

Technological change also helps account for the decline in employment in lumber and wood products. Plywood mills constructed in the South were state-of-the-art and required less labor than those that closed in the Pacific Northwest. 
The Importance of the Canadian Connection
Most of the southern plywood mills constructed after 1970 were located outside the mid-South and eastern Texas. By the end of the decade, no more southern pine plywood mills were being planned. Some plywood mills had closed and others had merged, signaling a shakeout 6 f of the industry (Cleaves and O'Laughlin 1985). The southern pine plywood production capacity may have peaked as the result of the scarcity of sawtimber and the substitution of manufactured board processed from smaller softwood logs or from hardwoods (Rush 1984).

Technological advances in the plywood industry and the shakeout of the southern plywood industry help explain the declining shares of lumber and wood products employment in the Pacific Northwest and the mid-South. A complete explanation, however, involves lumber imports from Canada.

Canada competes with the South and the Pacific Northwest for domestic lumber markets. In 1980, about 77 percent of lumber exports from Canada are destined for the United States (Statistics Canada 1981a, 1981b). Although Canadian producers have a tendency to move in and out of U.S. markets, the long-term trend has been upward. For example, in 1970, Canadians furnished 12 percent of the lumber used in the United States, but by 1979 their share had increased to 28 percent. 기

The consumption of softwood lumber in the United States increased substantially during the 1970's. In 1980, consumption was 10 percent higher than in 1970 but down from the peak of 1978-79. Although the South and the North increased production of softwood lumber, this increase was barely equal to the decrease in production in the West. Meanwhile, as the result of an increasingly favorable exchange rate for U.S. dollars, the Canadians provided most of the increase in apparent U.S. consumption of softwood lumber (that is, total domestic production plus imports, minus exports). During this period employment in the lumber and wood products industry increased. In British Columbia, for example, total employment in the logging and sawmill segments increased by nearly 15,000 workers between 1970 and 1980 (Statistics Canada 1972, 1982).

\footnotetext{
6/ Shakeout is one of five fundamental stages of productmarket development evolution: development, growth, shakeout, maturity-saturation, and decline (Hofer and Schendel 1978).

7] Unpublished keynote address of the Western Forest Economists (WFE) meeting, May 1980, by C.W.

Bingham, Weyerhaeuser Company, Tacoma, WA 98477.
} 
Change in U.S. softwood lumber production, imports, exports, and apparent consumption between 1970 and 1980

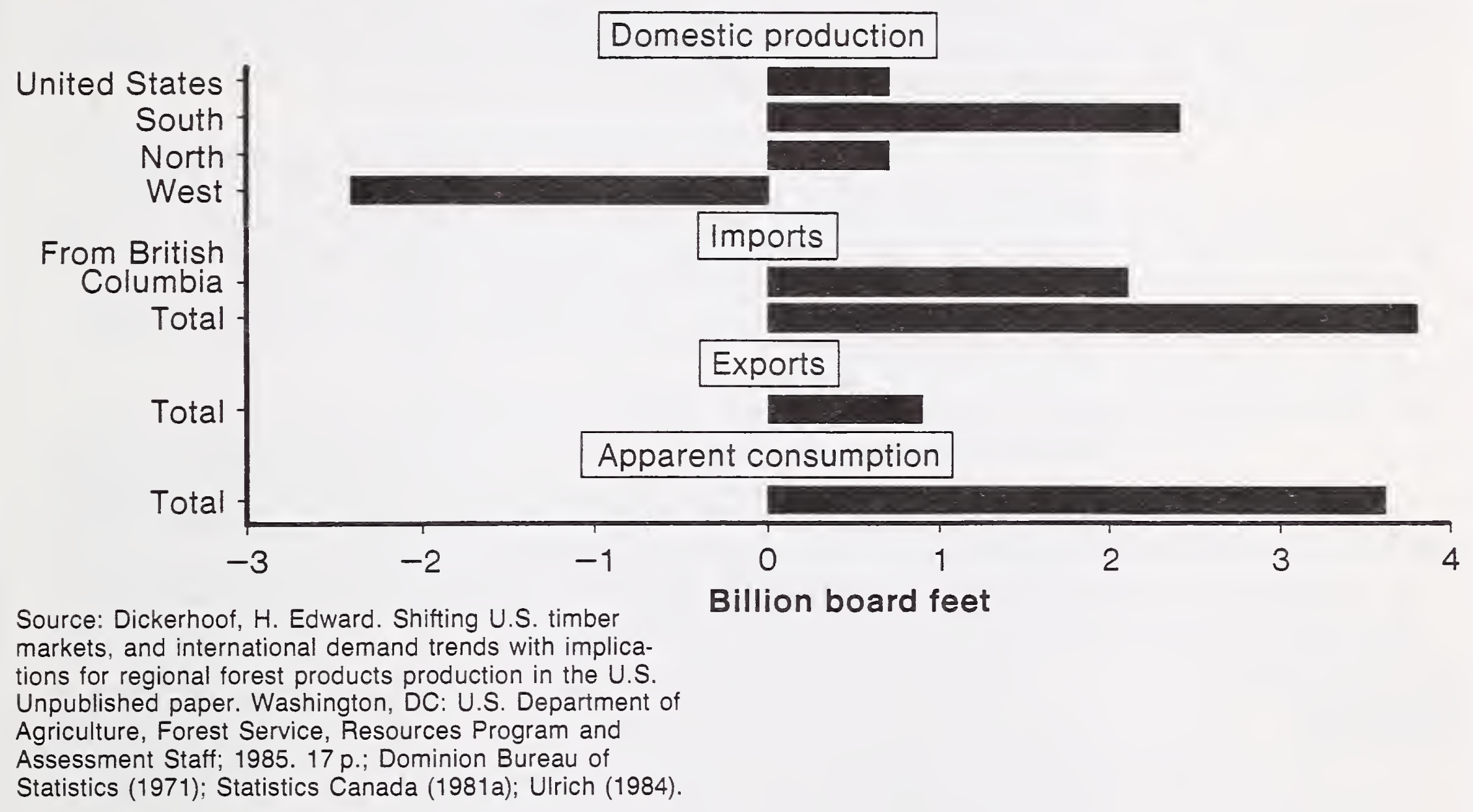


Anticipating Future Employment

Domestic lumber prices increased substantially during the 1970's, but the increase would have been greater without the availability of low-cost Canadian lumber. Furthermore, as McKillop and others (1981) pointed out, "Rising timber prices lead to the displacement of lumber and wood products by substitute materials such as concrete and steel. . . ." Any displacement, of course, would result in fewer jobs in the region's forest products industry now and in the future.

The future of the forest products industry in Canada is not encouraging. Reports reveal that the liquidation of forest resources-pulpwood as well as sawtimber inventories-is progressing at a rapid pace (O'Hara 1985). The production of paper products as well as lumber and wood products could be drastically curtailed in the near future. Pulpwood stands are being harvested faster than they are being regenerated in eastern Canada. Fires and insect attacks have also reduced the pulpwood resource.

Short of extraordinary measures to regenerate a large backlog of cutover areas and to improve utilization, British Columbia's sustainable rate of timber harvesting may be reduced to approximately 50 percent of the 1974 annual rate of harvest 8 / (that is, from roughly 100 million cubic meters to 50 million cubic meters). Because 70 percent of British Columbia's lumber production is exported-80 percent to the United States (Statistics Canada 1981a) -a fall down of such proportions would undoubtedly have international repercussions.

As in the past, the employment requirements of the forest products industry in the Pacific Northwest will continue to be influenced by interregional and international competition. Were it not for lumber imports from Canada, 1980 employment in the forest products industry, in the South as well as in the Pacific Northwest, undoubtedly would have been larger. Goldy (1985) asserts that future employment in the Pacific Northwest could increase if Canadian lumber production decreases.

Presumably, employment in both the Pacific Northwest and the South will increase if Canadian lumber production decreases, but the latest projections suggest that the South has more to gain in the long run than has the Pacific Northwest. Annual harvests of softwoods in the South were projected to increase 50 percent between 1976 and 2000 (USDA Forest Service 1982). Meanwhile, the annual harvest in the Pacific Northwest is expected to decline by 3 percent. $9 /$

\footnotetext{
8) Reshaping forest policy in British Columbia; unpublished paper prepared for the Vancouver Institute, Saturday Evening Lecture Series, Feb. 16, 1985, by F.L.C. Reed, University of British Columbia, Vancouver, BC, Canada V6t 1 W5.

9/ The fall down will be most noticeable in western Oregon. Beuter and others (1976) describe how a fall down in this area could be avoided.
} 
Projections for the South, however, may be too optimistic and may be revised when the study, "The South's Fourth Forest: Alternatives for the Future," is completed (Peterson 1985). The study was undertaken because of unforeseen developments in the timber supply and demand situation in the South. Preliminary findings disclosed that softwood "timber removals, for the first time in decades, are beginning to rise above net annual growth" and that "the rapid rise in the softwood inventories, the base for the expansion of the forest industries, can no longer be sustained" (Peterson 1985).

Crowell's (1985) assertion that "We can safely assume that the Pacific Northwest will continue to be the premier timber-producing region of the United States" has merit. The Pacific Northwest began the 1980's with approximately 2.1 times as much sawtimber as all 13 States of the South combined. Unlike Canada and the South, most of the Pacific Northwest forest ownerships are dedicated to forest management. Regeneration of softwood cutover lands continues to be a challenge, but the region's problem areas do not compare with those in Canada and the South.

An increase in employment in the United States resulting from a reduction in lumber imports may not match the decline in employment in Canada. For instance, should the cost of lumber increase as timber supplies decline, more wood substitutes will be preferred. Furthermore, for lumber to remain competitive with wood substitutes, domestic logging and lumber processing facilities will probably have to be less labor intensive than they now are.

Slow recovery of the Nation's homebuilding activity and competition from Canada and the South continue to plague the forest products industry in the Northwest. The long-term prospects for increasing demand for the region's forest products, however, are encouraging. But this does not mean that public and private policymakers should wait to see if softwood timber supplies decline in the South and Canada or that they should wait for the region's second-growth timber to mature. Anticipation of an increase in the future demand for the region's solid softwood timber products should be matched with accelerated efforts to improve the efficiency of logging and processing methods and the productivity of the timber resources. Such a matchup will help to assure that the forest products industry will increase its contribution to the region's economic growth and development. 


\section{Literature Cited}

Bendavid, Avrom. Regional economic analysis for practitioners: an introduction to common descriptive methods. New York: Praeger Publishers; 1974. 195 p.

Beuter, J.H.; Johnson, K.N.; Scheurman H.L. Timber for Oregon's tomorrow-an analysis of reasonable plausible occurrences. Res. Bull. 19. Corvallis, OR: Oregon State University, Forest Research Laboratory; 1976. 111 p.

Cardellichio, Peter A. Can transportation rates explain the West's loss of lumber market share? FORSIM Review. Lexington, MA: Data Resources, Inc.; 1980; 11(3): 73-79.

Cleaves, David A.; O'Laughlin, Jay. Forest inventory, plant location and company strategies. In: Proceedings of the 1985 southern forest economic workers (SOFEW) workshop; 1985 March 13-15; Athens, GA. Athens, GA: University of Georgia; 1985: 35-43.

Crowell, John B., Jr. Timber contract relief: will it work? Oregon Business. 8(1): 24-28; 1985.

Data Resources, Inc. Timber mart-south, 1983. Lexington, MA; 1984. 291 p.

Dickerhoof, H. Edward; Youngquist, John A.; Caril, Charles G. U.S. woodbased panel industry: production trends and changing markets. Forest Products Journal. 32(6): 14-23; 1982.

Dominion Bureau of Statistics. Production, shipments and stocks on hand of sawmills in British Columbia. 24(12): 1-12. Ottawa, ON: Manufacturing and Primary Industrial Division; 1971.

Goldy, Daniel L. Quotable notables on timber. Portland. 12(8): 20-22; 1985.

Hofer, Charles W.; Schendel, Dan. Strategy formulation: analytical concepts. St. Paul, MN: West Publishing Company; 1978. 219 p.

McKillop, William; Adams, Darius M.; Haynes, Richard W. National impacts of softwood product price increases. Journal of Forestry. 79(12): 807-810; 1981.

O'Hara, Jane. Canada's vanishing forest. Maclean's. 98(2): 36-42; 1985.

Peterson, R. Max. Timber supply--the situation in the South. Forest Farmer. 44(9): 14-16; 1985.

Rush, Donald E. An industrial forest owner's view of the southern pine supply. Stillwater, OK: Oklahoma State University, Department of Forestry; 1984. 6 p. [Nat Walker Lectureship, April 1984].

Statistics Canada. Canadian forestry statistics 1970. Ottawa, ON: Manufacturing and Primary Industrial Division; 1972. Cat. 25-202 Annu. 25 p. 
Statistics Canada. Production, shipments and stocks on hand of sawmills east of the Rockies, excluding Newfoundland and Prince Edward Island. 35(12): 1-12. Ottawa, ON: Manufacturing and Primary Industrial Division; 1981a.

Statistics Canada. Production, shipments and stocks on hand of sawmills in British Columbia. 35(12): 1-9. Ottawa, ON: Manufacturing and Primary Industrial Division; $1981 b$.

Statistics Canada. Canadian forestry statistics 1980. Ottawa, ON: Manufacturing and Primary Industrial Division; 1982. Cat. 25-202 Annu. 43 p.

Uirich, Alice H. U.S. timber production, trade, consumption, and price statistics, 1950-83. Misc. Publ. 1442. Washington, DC: U.S. Department of Agriculture; 1984. $83 \mathrm{p}$.

U.S. Bureau of the Census. 1970 county business patterns. Washington, DC: U.S. Department of Commerce; 1971. [Separates for each State].

U.S. Bureau of the Census. 1980 county business patterns. Washington, DC: U.S. Department of Commerce; 1981. [Separates for each State].

U.S. Department of Agriculture, Forest Service. An analysis of the timber situation in the United States 1952-2030. For. Resour. Rep. 23. Washington, DC: U.S. Department of Agriculture; 1982. 499 p. 
Appendix 1 Tables
Table 1-Total labor and proprietorial employment and earnings, by industry, Oregon and Washington, 1980

\begin{tabular}{|c|c|c|}
\hline $\begin{array}{l}\text { State and } \\
\text { industry } \\
\text { by number }\end{array}$ & Employees & $\begin{array}{c}\text { Total } \\
\text { earnings }\end{array}$ \\
\hline & Number & $\begin{array}{c}\text { Million } \\
1977 \\
\text { dollars } 1\end{array}$ \\
\hline
\end{tabular}

OREGON:
Wage and Salary-
1 Agriculture
2 Agricultural services, forestry, and fisheries
3 Coal mining
4 Oil and gas extraction
5 Metal mining
6 Nonmetallic minerals
7 Construction
8 Food and kindred products
9 Tobacco
10 Textile mill production
11 Apparel and other textiles
12 Paper and allied products
13 Printing and publishing
14 Chemical and allied products
15 Petroleum refining
16 Rubber and miscellaneous plastics
17 Leather and leather products
18 Lumber and wood products, except mobile homes
19 Mobile homes
20 Wood furniture
21 Other furniture and fixtures
22 Stone, clay, and glass products
23 Primary metals
24 Fabricated metals
25 Machinery, excluding electrical
26 Electrical machinery
27 Transportation equipment except motor vehicles
28 Motor vehicles
29 Ordnance
30 Instruments and related equipment
31 Miscellaneous manufacturing
32 Railroad transportation

26,519

334,663

9,947

38

31

270

1,623

46,598

24,384

2,034

3,193

10,356

10,039

2,265

624

2,440

268

67,269

2,300

1,725

852

4,441

10,944

12,638

17,795

9,759

6,160

4,146

2)

19,102

2,160

7,313
121,339

923

684

4,257

26,904

$1,000,254$

316,866

21,448

29,940

221,345

132,672

39,233

12,724

33,446

3,285

$1,177,773$

40,269

21,095

10,419

82,980

245,341

205,635

314,369

142,123

124,145

91,117 2)

290,674

29,282

140,127

See footnotes at end of table. 
Table 1-Total labor and proprietorial employment and earnings, by industry, Oregon and Washington, 1980 (continued)

State and

industry

by number

Employees

Total

earnings

Million

1977

Number

dollars ${ }^{1 /}$

OREGON:

Wage and Salary-

33 Trucking and warehousing

34 Local transit

35 Air transportation

36 Pipeline transportation

37 Transportation services

38 Water transportation

39 Communications

40 Electrical, gas, and sanitation services

17,583

3,113

2,120

19

2,550

2,559

16,263

346,974

30,446

36,089

414

40,943

57,021

303,983

41 Wholesale trade

42 Retail trade

43 Banking

44 Other credit agencies

45 Insurance

8,794

192,004

67,468

$1,097,783$

188,158

17,349

$1,632,262$

10,015

191,974

151,371

19,229

298,337

46 Real estate and combinations

13,616

256,937

47 Hotel and other lodging

15,030

95,659

48 Personal, miscellaneous business, and repair services

37,795

452,996

49 Auto repair service

6,857

110,014

7,217

48,708

1,936

9,615

13,511

33,201

62,059

9,496

32,087

16,670

29,497

13,737

173,875

875,484

77,918

143,045

504,726

462,337

50,000

$1,787,921$

Proprietorial-

60 Farm proprietors

40,449

151,115

61 Nonfarm proprietors

Total

See footnotes at end of table. 
Table 1-Total labor and proprietorial employment and earnings, by industry, Oregon and Washington, 1980 (continued)

State and industry by number

Number

dollars ${ }^{1 /}$

WASHINGTON:

Wage and salary-

1 Agriculture

44,749

624,629

2 Agricultural services, forestry, and fisheries

16,036

558

252,385

3 Coal mining

4 Oil and gas extraction

13,555

5 Metal mining

853

1,347

6 Nonmetallic minerals

1,579

14,694

7 Construction

92,826

8 Food and kindred products

31,038

29,910

9 Tobacco

10 Textile mill production

1,051

6,477

11 Apparel and other textiles

17,507

12 Paper and allied products

15,817

13 Printing and publishing

8,711

$1,882,260$

457,632

2,046

15 Petroleum refining

3,460

365

9,767

57,861

376,540

210,634

174,795

62,460

49,715

17 Leather and leather products

3,983

18 Lumber and wood products, except mobile homes

45,564

818,776

19 Mobile homes

929

16,694

2,002

25,828

21 Other furniture and fixtures

1,304

16,823

22 Stone, clay and glass products

6,829

123,899

23 Primary metals

16,678

391,117

24 Fabricated metals

11,840

217,541

25 Machinery, excluding electrical

14,958

266,644

11,514

168,505

27 Transportation equipment except motor vehicles

96,080

$2,155,551$

2,330

21

49,924

29 Ordnance

6,346

2)

30 Instruments and related equipment

4,654

92,963

31 Miscellaneous manufacturing

10,552

59,179

32 Railroad transportation

200,767

33 Trucking and warehousing

20,801

386,167

3,248

36,113

35 Air transportation

36 Pipeline transportation

9,488

219,656

37 Transportation services

85,827

38 Water transportation

5,611

8,026

181,516

39 Communications

26,588

517,384

See footnotes at end of table. 
Table 1-Total labor and proprietorial employment and earnings, by industry, Oregon and Washington, 1980 (continued)

State and industry by number

Million

1977

Number dollars $1 /$

WASHINGTON:

Wage and salary-

40 Electrical, gas, and sanitation services

41 Wholesale trade

100,201

$1,687,026$

42 Retail trade

281,163

$2,506,777$

43 Banking

44 Other credit agencies

28,379

353,018

14,058

235,904

45 Insurance

29,551

46 Real estate and combinations

22,659

483,558

47 Hotel and other lodging

18,066

335,027

48 Personal, miscellaneous business, and repair services

74,344

129,303

49 Auto repair service

11,269

$1,035,649$

14,308

174,083

50 Amusement

51 Motion pictures

3,126

102,284

52 Private households

22,331

18,991

53 Medical and other health

95,426

55,746

54 Private education

55 Nonprofit organizations

54,939

113,156

56 Miscellaneous services

29,458

320,600

57 Federal civilian

67,140

836,556

$68,0,94$

$1,059,114$

58 Federal military

259,721

530,597

59 State and local government

$3,000,665$

\section{Proprietorial-}

60 Farm proprietors

61 Nonfarm proprietors

Total

1 The personal consumption expenditures (PCE) deflator, $1977=100$, was used to deflate actual dollars.

2/Included with fabricated metals.

Source: unpublished data, U.S. Department of Commerce, Regional Economics Measurements Division, Regional Economic Information System (REIS), Washington, DC, 1982. Unpublished data used by the U.S. Department of Commerce in preparing their County Business Patterns (CBP) series on employment and payroll were used to differentiate wood-related from nonwood-related employment and earnings. For example, CBP data were used to separate mobile homes (19) from the lumber and wood products industry (18) and wood furniture (20) from other furniture and fixtures (21). 
Table 2-Calculation of dependency indexes for Oregon, 1980

\begin{tabular}{|c|c|c|c|c|}
\hline \multirow[b]{2}{*}{ Industry } & \multicolumn{2}{|c|}{ Employment } & \multirow{2}{*}{$\begin{array}{c}\text { Oregon } \\
\text { excess } \\
\text { employment } 1 /\end{array}$} & \multirow[b]{2}{*}{$\begin{array}{l}\text { Dependency } \\
\text { index } 2\end{array}$} \\
\hline & Oregon & $\begin{array}{l}\text { United } \\
\text { States }\end{array}$ & & \\
\hline & \multicolumn{4}{|c|}{ Percent } \\
\hline Agriculture & 2.50 & 1.46 & 1.04 & 6.80 \\
\hline $\begin{array}{l}\text { Agricultural services, } \\
\text { forestry, and fisheries }\end{array}$ & .94 & .62 & .32 & 2.09 \\
\hline Farm proprietors & 3.81 & 3.03 & .78 & 5.12 \\
\hline Coal mining & 0 & .27 & -- & -- \\
\hline Oil and gas extraction & 0 & .60 & -- & -- \\
\hline Metal mining & .03 & .11 & -- & -- \\
\hline Nonmetallic minerals & .15 & .14 & .02 & .11 \\
\hline Construction & 4.39 & 4.74 & -- & -. \\
\hline Food and kindred products & 2.30 & 1.87 & .43 & 2.81 \\
\hline Textile mill production & .19 & .93 & -- & -- \\
\hline Tobacco & 0 & .07 & -- & -- \\
\hline Apparel and other textiles & .30 & 1.39 & -- & -. \\
\hline Paper and allied products & .98 & .76 & .22 & 1.44 \\
\hline Printing and publishing & .95 & 1.37 & -- & -- \\
\hline Chemical and allied products & .21 & 1.22 & -- & -- \\
\hline Petroleum refining & .06 & .22 & -- & -. \\
\hline Rubber and miscellaneous plastics & .23 & .80 & -- & -- \\
\hline Leather and leather products & .03 & .26 & -- & -- \\
\hline Lumber and wood products, & & & & \\
\hline except mobile homes & 6.34 & .71 & 5.63 & 36.86 \\
\hline Mobile homes & .22 & .05 & .17 & 1.09 \\
\hline Wood furniture & .16 & .32 & -- & -- \\
\hline Other furniture and fixtures & .08 & .19 & -- & -- \\
\hline Stone, clay, and glass products & .42 & .73 & -- & -- \\
\hline Primary metals & 1.03 & 1.26 & -- & -- \\
\hline Fabricated metals & 1.19 & 1.77 & -- & -- \\
\hline Machinery, excluding electrical & 1.68 & 2.73 & -- & -- \\
\hline Electrical machinery & .92 & 2.31 & -- & -- \\
\hline Transportation equipment, except & & & & \\
\hline motor vehicles & .58 & 1.21 & -- & -- \\
\hline Motor vehicles & .39 & .87 & -- & -- \\
\hline Instruments and related & & & & \\
\hline equipment & 1.80 & .77 & 1.03 & 6.72 \\
\hline Miscellaneous manufacturing & .20 & .47 & -- & -- \\
\hline Railroad transportation & .69 & .58 & .11 & .69 \\
\hline Trucking and warehousing & 1.66 & 1.40 & .26 & 1.68 \\
\hline Local transit & .29 & .29 & -- & -- \\
\hline Air transportation & .20 & .50 & -- & -- \\
\hline Pipeline transportation & 0 & .02 & -- & -- \\
\hline Transportation services & .24 & .22 & .02 & .11 \\
\hline
\end{tabular}

See footnotes at end of table. 
Table 2-Calculation of dependency indexes for Oregon, 1980 (continued)

\begin{tabular}{|c|c|c|c|c|}
\hline \multirow[b]{2}{*}{ Industry } & \multicolumn{2}{|c|}{ Employment } & \multirow{2}{*}{$\begin{array}{c}\text { Oregon } \\
\text { excess } \\
\text { employment } 1 /\end{array}$} & \multirow[b]{2}{*}{$\begin{array}{l}\text { Dependency } \\
\text { index } 2 /\end{array}$} \\
\hline & Oregon & $\begin{array}{l}\text { United } \\
\text { States }\end{array}$ & & \\
\hline & \multicolumn{4}{|c|}{ Percent } \\
\hline Water transportation & .24 & .23 & .01 & .08 \\
\hline Communications & 1.53 & 1.48 & .05 & .34 \\
\hline Electrical, gas, and & & & & \\
\hline sanitation services & .83 & .90 & -- & -. \\
\hline Wholesale trade & 6.36 & 5.79 & .57 & 3.76 \\
\hline Retail trade & 17.74 & 16.50 & 1.24 & 8.09 \\
\hline Banking & 1.64 & 1.72 & -- & -- \\
\hline Other credit agencies & .94 & .99 & -- & -- \\
\hline Insurance & 1.81 & 1.89 & -- & -- \\
\hline Real estate and combinations & 1.28 & 1.16 & .12 & .81 \\
\hline Hotel and other lodging & 1.42 & 1.20 & .22 & 1.42 \\
\hline \multicolumn{5}{|l|}{ Personal, miscellaneous } \\
\hline business, and repair services & 3.56 & 4.69 & -- & -- \\
\hline Auto repair service & .65 & .63 & .02 & .11 \\
\hline Amusement & .68 & .84 & -- & -- \\
\hline Motion pictures & .18 & .24 & -- & -- \\
\hline Medical and other health & 5.85 & 5.71 & .14 & .90 \\
\hline Private education & .90 & 1.47 & -- & -- \\
\hline Nonprofit organizations & 3.02 & 3.01 & .01 & .09 \\
\hline Miscellaneous services & 1.57 & 1.63 & -- & -- \\
\hline Federal civilian & 2.78 & 3.27 & -- & -- \\
\hline Federal military & 1.29 & 2.68 & -- & -- \\
\hline Nonfarm proprietors & 10.55 & 7.66 & 2.89 & 18.89 \\
\hline Total $3 /$ & 100.00 & 100.00 & 15.28 & 100.00 \\
\hline
\end{tabular}

1) U.S. employment share minus Oregon employment share. Figures may not be equal to Oregon minus United States because of rounding. Dashes signify no excess employment.

2/ Excess employment of each industry expressed as a percentage of Oregon total excess employment.

3/ Totals may not be exact because of rounding. 
Table 3-Calculation of dependency indexes for Washington, 1980

\begin{tabular}{|c|c|c|c|c|}
\hline \multirow[b]{2}{*}{ Industry } & \multicolumn{2}{|c|}{ Employment } & \multirow{2}{*}{$\begin{array}{l}\text { Washington } \\
\text { excess } \\
\text { employment } 1 / 1\end{array}$} & \multirow{2}{*}{$\begin{array}{c}\text { Dependency } \\
\text { index } 2 /\end{array}$} \\
\hline & Washingtor & $\begin{array}{l}\text { United } \\
\text { States }\end{array}$ & & \\
\hline
\end{tabular}

Agriculture

Agricultural services, forestry, and fisheries

Percent

Farm proprietors

Coal mining

Oil and gas extraction

Metal mining

Nonmetallic minerals

Construction

Food and kindred products

Tobacco

Textile mill production

Apparel and other textiles

Paper and allied products

Printing and publishing

Chemical and allied products

Petroleum refining

Rubber and miscellaneous plastics

Leather and leather products

Lumber and wood products, except mobile homes

Mobile homes

Wood furniture

Other furniture and fixtures

Stone, clay, and glass products

Primary metals

Fabricated metals

Machinery, excluding electrical

Electrical machinery

2.68

1.46

1.22

8.60

.96

.62

2.61

3.03

.03

.27

0

.05

.11

.09

.14

5.56

4.74

1.86

1.87

0

$\begin{array}{ll}.06 & .93\end{array}$

.39

1.39

1.05

.76

.95

1.37

.52

1.22

.12

Transportation equipment, except motor vehicles

.69

2.31
motor vehicles

\subsection{6}

1.21

Instruments and related equipment

Miscellaneous manufacturing

Railroad transportation 
Table 3-Calculation of dependency indexes for Washington, 1980 (continued)

\begin{tabular}{|c|c|c|c|c|}
\hline \multirow[b]{2}{*}{ Industry } & \multicolumn{2}{|c|}{ Employment } & \multirow{2}{*}{$\begin{array}{l}\text { Washington } \\
\text { excess } \\
\text { employment }{ }^{1 /}\end{array}$} & \multirow{2}{*}{$\begin{array}{c}\text { Dependency } \\
\text { index } 2 \text { / }\end{array}$} \\
\hline & Washington & $\begin{array}{l}\text { United } \\
\text { States }\end{array}$ & & \\
\hline & \multicolumn{4}{|c|}{ Percent } \\
\hline Air transportation & .57 & .50 & .07 & .49 \\
\hline Pipeline transportation & .01 & .02 & -- & -- \\
\hline Transportation services & .34 & .22 & .11 & .80 \\
\hline Water transportation & .48 & .23 & .25 & 1.77 \\
\hline Communications & 1.59 & 1.48 & .11 & .79 \\
\hline Electric, gas, and & & & & \\
\hline sanitation services & .44 & .90 & -- & -- \\
\hline Wholesale trade & 6.01 & 5.79 & .22 & 1.55 \\
\hline Retail trade & 16.86 & 16.50 & .35 & 2.50 \\
\hline Banking & 1.70 & 1.72 & -- & -- \\
\hline Other credit agencies & .84 & .99 & -- & -- \\
\hline Insurance & 1.77 & 1.89 & -- & -- \\
\hline Real estate and combinations & 1.36 & 1.16 & .20 & 1.39 \\
\hline Hotel and other lodging & 1.08 & 1.20 & -- & -- \\
\hline \multicolumn{5}{|l|}{ Personal, miscellaneous } \\
\hline business, and repair services & 4.46 & 4.69 & -- & -- \\
\hline Auto repair service & .68 & .63 & .05 & .32 \\
\hline Amusement & .86 & .84 & .02 & .11 \\
\hline Motion pictures & .19 & .24 & -- & -- \\
\hline Medical and other health & 5.72 & 5.71 & .01 & .06 \\
\hline Private education & .78 & 1.47 & -- & -- \\
\hline Nonprofit organizations & 3.29 & 3.01 & .28 & 1.98 \\
\hline Miscellaneous services & 1.77 & 1.63 & .13 & .92 \\
\hline Federal civilian & 4.02 & 3.27 & .76 & 5.32 \\
\hline Federal military & 4.08 & 2.68 & 1.40 & 9.87 \\
\hline Nonfarm proprietors & 8.60 & 7.66 & .94 & 6.62 \\
\hline Total ${ }^{3 /}$ & 100.00 & 100.00 & 14.20 & 100.00 \\
\hline
\end{tabular}

1/ U.S. employment share minus Washington employment share. Figures may not be equal to Washington minus United States because of rounding. Dashes signify no excess employment.

2/ Excess employment of each industry expressed as a percentage of Washington total excess employment.

3) Totals may not be exact because of rounding. 
Table 4-Value added, payroll, hours worked, and profits of the forest products industry in the Pacific Northwest and in regions of the South, 1977

\begin{tabular}{llccc}
\hline $\begin{array}{l}\text { Region } \\
\text { and } \\
\text { industry }\end{array}$ & $\begin{array}{l}\text { Value } \\
\text { added }\end{array} \quad$ Payroll & $\begin{array}{c}\text { Hours } \\
\text { worked }\end{array}$ & Profits $1 /$ & $\begin{array}{c}\text { Change in } \\
\text { profits, } \\
1972-77\end{array}$ \\
\hline & Million dollars & Million & \$VAMP/hour & Percent
\end{tabular}

Pacific Northwest:

Lumber and wood products Wood furniture Paper and allied products

Total or

average 2 /

$\begin{array}{rrrrr}3,831 & 1,734 & 212 & 9.92 & 14.27 \\ 72 & 37 & 6 & 5.85 & 26.43\end{array}$

$1,327 \quad 472$

41

20.97

32.39

5,230

2,242

258

11.57

18.69

South:

Lumber and wood products $4,707 \quad 2,025 \quad 38$ 384

6.98 30.69

Wood furniture 2,519 1,286 269

4.58

Paper and allied products

$\underline{7,114 \quad 2,599}$

Total or average 2 14,340

5,910

940

8.97

29.69

South Atlantic:

Lumber and wood products

Wood furniture

Paper and allied products

\begin{tabular}{rrrrr}
1,984 & 871 & 165 & 6.74 & 26.37 \\
1,704 & 865 & 183 & 4.59 & 4.50 \\
3,217 & 1,241 & 136 & 14.48 & 32.69 \\
\hline & & & & \\
6,905 & 2,977 & 484 & 8.11 & 24.00
\end{tabular}

Total or average 2 6,905

\begin{tabular}{rr}
802 & 370 \\
320 & 174 \\
1,776 & 577 \\
\hline
\end{tabular}

Total or average 21 2,898 
Table 4-Value added, payroll, hours worked, and profits of the forest products industry in the Pacific Northwest and in regions of the South, 1977 (continued)

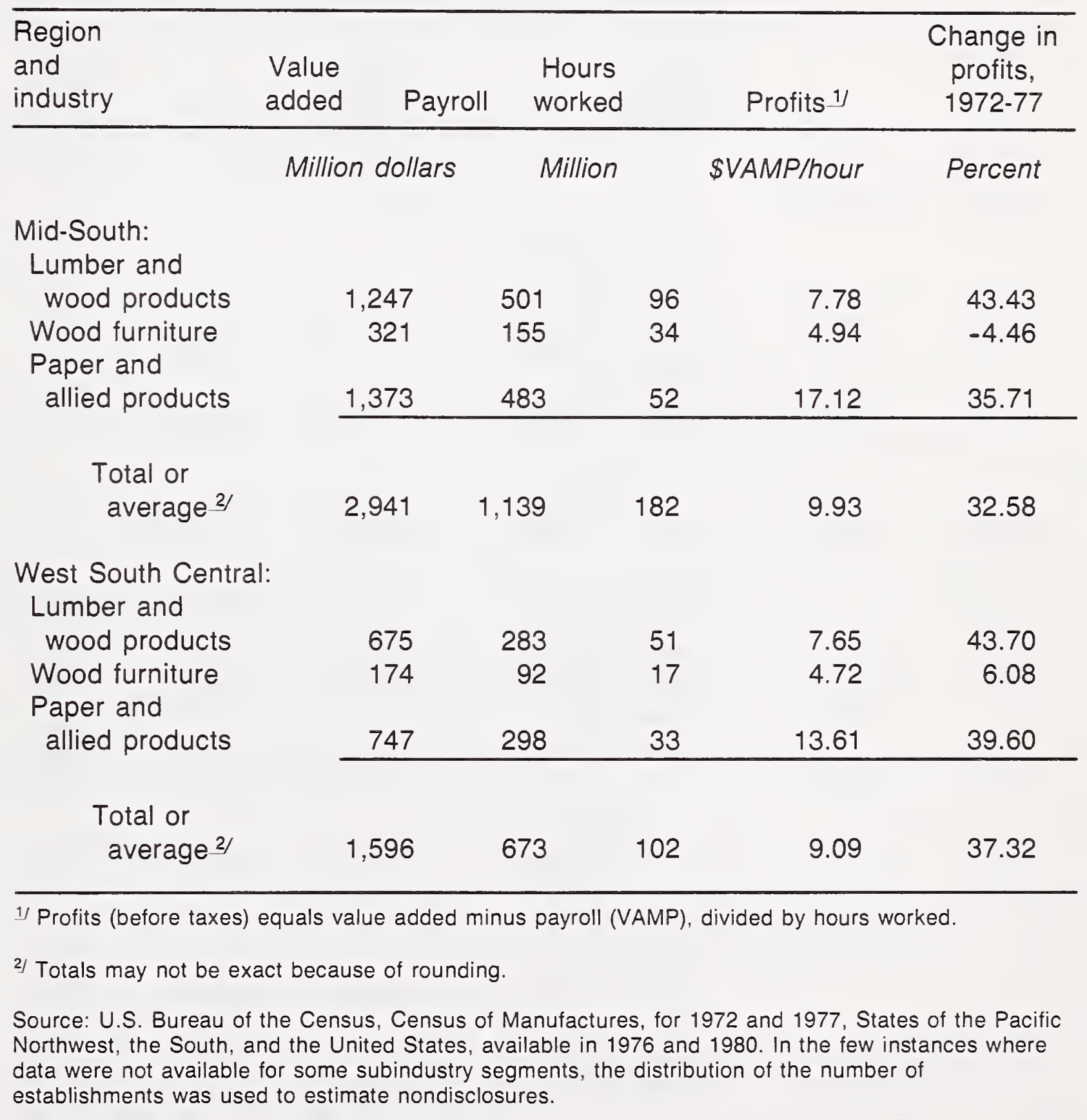


Table 5-Value added, payroll, hours worked, and profits of the forest products industry in the Pacific Northwest and in regions of the South, 1982

\begin{tabular}{lllll}
\hline $\begin{array}{l}\text { Region } \\
\text { and } \\
\text { industry }\end{array}$ & $\begin{array}{l}\text { Value } \\
\text { added }\end{array} \quad$ Payroll & $\begin{array}{c}\text { Hours } \\
\text { worked }\end{array} \quad$ Profits $1 / 19$ & $\begin{array}{c}\text { Change in } \\
\text { profits, } \\
1977-82\end{array}$ \\
\hline & Million dollars & Million & \$VAMP/hour & Percent
\end{tabular}

Pacific Northwest:

Lumber and wood products

Wood furniture

Paper and allied products

$\begin{array}{rrrrr}1,808 & 1,155 & 136 & 4.81 & -51.52 \\ 56 & 25 & 4 & 8.21 & 40.35\end{array}$

\begin{tabular}{lllll}
1,056 & 447 & 34 & 17.65 & -15.84 \\
\hline
\end{tabular}

Total or average ${ }^{2}$ $2,920 \quad 1,627$

174

7.43

$-35.81$

South:

Lumber and wood products Wood furniture Paper and allied products

\begin{tabular}{rrrrr}
3,380 & 1,749 & 334 & 4.88 & -30.04 \\
2,159 & 1,106 & 225 & 4.66 & 1.73 \\
& & & & \\
7,482 & 2,733 & 285 & 16.65 & -5.35 \\
\hline & & & & \\
13,022 & 5,593 & 844 & 8.80 & -1.97
\end{tabular}

Total or average 2 $13,022 \quad 5,593$

$\begin{array}{lllll}1,563 & 804 & 154 & 4.92 & -26.95 \\ 1,476 & 782 & 156 & 4.46 & -2.81\end{array}$

Paper and allied products

$$
3,370
$$

1,298

136

15.20

4.98

\section{Total or} average 21

$6,409 \quad 2,884$

446

7.90

$-2.56$

East South Central:

$$
\begin{aligned}
& \text { Lumber and } \\
& \text { wood products } \\
& \text { Wood furniture } \\
& \text { Paper and } \\
& \text { allied products }
\end{aligned}
$$

\section{Total or} average ${ }^{2 /}$ 
Table 5-Value added, payroll, hours worked, and profits of the forest products industry in the Pacific Northwest and in regions of the South, 1982 (continued)

\begin{tabular}{|c|c|c|c|c|c|}
\hline $\begin{array}{l}\text { Region } \\
\text { and } \\
\text { industry }\end{array}$ & $\begin{array}{l}\text { Value } \\
\text { added }\end{array}$ & Payroll & $\begin{array}{l}\text { Hours } \\
\text { worked }\end{array}$ & Profits ${ }^{1 /}$ & $\begin{array}{c}\text { Change in } \\
\text { profits, } \\
1977-82\end{array}$ \\
\hline & \multicolumn{2}{|c|}{ Million dollars } & Million & \$VAMP/hour & Percent \\
\hline \multicolumn{6}{|l|}{ Mid-South: } \\
\hline wood products & 749 & 386 & 73 & 4.99 & -35.83 \\
\hline \multicolumn{5}{|l|}{ Paper and } & 28.34 \\
\hline allied products & 1,245 & 476 & 47 & 16.39 & -4.25 \\
\hline $\begin{array}{l}\text { Total or } \\
\text { average } 2 /\end{array}$ & 2,256 & 975 & 143 & 8.95 & -9.86 \\
\hline \multicolumn{6}{|c|}{ West South Central: } \\
\hline wood products & 529 & 273 & 48 & 4.43 & -30.33 \\
\hline \multicolumn{6}{|l|}{ Paper and } \\
\hline allied products & 789 & 322 & 35 & 13.18 & -3.31 \\
\hline $\begin{array}{l}\text { Total or } \\
\text { average } 21\end{array}$ & 1,439 & 659 & 96 & 8.12 & -10.67 \\
\hline $\begin{array}{l}\text { "Profits (before taxes } \\
\text { 2/ Totals may not be e }\end{array}$ & value ad & $\begin{array}{l}\text { minus pas } \\
\text { ding. }\end{array}$ & & Ad he houre ing & \\
\hline
\end{tabular}


Appendix 2

Oregon Counties by

Sub-State Planning and Development Districts
District code Counties

\section{Clatsop, Tillamook}

Columbia, Multnomah, Washington

Marion, Polk, Yamhill

Benton, Lincoln, Linn

Lane

Douglas

Coos, Curry

Jackson, Josephine

Hood River, Sherman, Wasco

Crook, Deschutes, Jefferson

Klamath, Lake

Gilliam, Grant, Morrow, Umatilla, Wheeler

Baker, Union, Wallowa

Harney, Malheur
Washington Counties by Sub-State Planning and Development Districts

\section{Counties}

Clallam, Jefferson

Grays Harbor, Pacific

Island, San Juan, Skagit, Whatcom

King, Kitsap, Pierce, Snohomish

Lewis, Mason, Thurston

Clark, Cowlitz, Klickitat, Skamania, Wahkiakum

Chelan, Douglas, Okanogan

Kittitas, Yakima

Adams, Grant, Lincoln

Benton, Franklin

Ferry, Pend Oreille, Stevens

Spokane

Asotin, Columbia, Garfield, Walla Walla, Whitman 
Schallau, Con H; Maki, Wilbur R. Economic impacts of interregional competition in the forest products industry during the 1970's: the South and the Pacific Northwest. Res. Pap. PNW-350. Portland, OR: U.S. Department of Agriculture, Forest Service, Pacific Northwest Research Station; 1986. 44 p.

Until the 1970's, the Pacific Northwest dominated national markets for softwood lumber and plywood. During the 1970's, however, the region's share declined while production increased in the South. Meanwhile, the South's and the Pacific Northwest's shares of the Nation's employment in lumber and wood products declined. This resulted mainly from the increase in lumber imports from Canada and the construction of new, state-of-the-art plywood mills in the South. Trends in Canada and the South suggest that the Pacific Northwest could regain its dominant position as the supplier of solid softwood products. Although employment in the forest products industry will unlikely return to past levels, the industry will continue to play an important role in the region's economic growth and development.

Keywords: Economic impact, interregional competition, economics (forest products industries), shift-share analysis, Canada, Pacific Northwest, South. 
The Forest Service of the U.S. Department of Agriculture is dedicated to the principle of multiple use management of the Nation's forest resources for sustained yields of wood, water, forage, wildlife, and recreation. Through forestry research, cooperation with the States and private forest owners, and management of the National Forests and National Grasslands, it strives - as directed by Congress - to provide increasingly greater service to a growing Nation.

The U.S. Department of Agriculture is an Equal Opportunity Employer. Applicants for all Department programs will be given equal consideration without regard to age, race, color, sex, religion, or national origin.

Pacific Northwest Research Station 319 S.W. Pine St.

P.O. Box 3890

Portland, Oregon 97208 

